\title{
Role of microRNAs in Diagnosis, Prognosis and Management of Multiple Myeloma
}

\author{
Amro M. Soliman ${ }^{1}(\mathbb{D})$, Teoh Seong Lin ${ }^{2, *(D)}$, Pasuk Mahakkanukrauh ${ }^{3}$ and Srijit Das ${ }^{2, *(D)}$ \\ 1 Department of Biological Sciences-Physiology, Cell and Developmental Biology, University of Alberta, \\ Edmonton, AB T6G 2R3, Canada; amsherif@ualberta.ca \\ 2 Department of Anatomy, Faculty of Medicine, Universiti Kebangsaan Malaysia Medical Centre, \\ Kuala Lumpur 56000, Malaysia \\ 3 Department of Anatomy \& Excellence in Osteology Research and Training Center (ORTC), \\ Chiang Mai University, Chiang Mai 50200, Thailand; pmahanka@mail.med.cmu.ac.th \\ * Correspondence: teohseonglin@ppukm.ukm.edu.my (T.S.L.); drsrijit@gmail.com (S.D.)
}

Received: 12 August 2020; Accepted: 2 October 2020; Published: 13 October 2020

\begin{abstract}
Multiple myeloma (MM) is a cancerous bone disease characterized by malignant transformation of plasma cells in the bone marrow. $\mathrm{MM}$ is considered to be the second most common blood malignancy, with 20,000 new cases reported every year in the USA. Extensive research is currently enduring to validate diagnostic and therapeutic means to manage MM. microRNAs (miRNAs) were shown to be dysregulated in MM cases and to have a potential role in either progression or suppression of MM. Therefore, researchers investigated miRNAs levels in MM plasma cells and created tools to test their impact on tumor growth. In the present review, we discuss the most recently discovered miRNAs and their regulation in MM. Furthermore, we emphasized utilizing miRNAs as potential targets in the diagnosis, prognosis and treatment of MM, which can be useful for future clinical management.
\end{abstract}

Keywords: multiple myeloma; cancer; miRNA; oncomiR; tumor suppressor; diagnostic marker

\section{Introduction}

Multiple myeloma (MM), also recognized as plasma cell myeloma, is a cancer of the plasma cells. MM develops in the bone marrow and originates from the long-lived plasma cells following their maturation in lymph nodes and migration to the bone marrow [1-3]. In most MM cases, the disease starts with pre-malignant asymptomatic stages, which eventually evolve to symptomatic intramedullary and extramedullary MM. A section of MM patients is pre-diagnosed with monoclonal gammopathy of undetermined significance (MGUS), which is found in around $3 \%$ of individuals over 50 years $[4,5]$. Nearly $1 \%$ of patients diagnosed with MGUS develop MM or other hematological malignancies [6-8]. Meanwhile, other patients are diagnosed with smoldering MM (SMM), an asymptomatic and more progressive pre-malignant stage, which could be detected through clinical examination and laboratory investigations [9]. Almost 10\% of SMM cases develop into MM during the first five years subsequent to the diagnosis [10].

$\mathrm{MM}$ is the second most common blood cancer, where it represents $1 \%$ of all cancers and about $13 \%$ of all hematologic malignancies globally [11-13]. The incidence rate of MM in Europe is 5 per 100,000 [14,15]. In the USA, almost 230,000 cases of MM at different stages were reported from 2011 to 2016, with around 20,000 new cases registered yearly [13,16]. Approximately $28.6 \%$ of MM cases are diagnosed at the age of 65-74 years, and about 3.5\% under the age of 44 years [17]. The incidence of MM in the black race is higher than the white race and is more common in males than females [18]. The median survival following standardized therapy is 3 to 4 years. However, bone marrow transplantation could expand survival to 7 years [19]. 


\section{Pathogenesis of MM}

The exact cause of MM remains unknown. However, a number of risk factors have been reported, including radiation, family history and obesity [20]. Furthermore, numerous genetic mutations are associated with MM development [21,22]. Approximately $90 \%$ of MM patients possess genetic defects in their plasma cells, which varies with the advancement of the disease. For instance, certain cytogenetic variations result in the evolvement of MGUS or SMM to MM [23]. These cytogenetic alternations include del(17p), $\mathrm{t}(11 ; 14)$ (q13;q32), del(13), $\mathrm{t}(4 ; 14)$ (p16;q32), t(14;20) (q32;q11), gain(1q), isolated monosomy 13, monosomy 14 and $\operatorname{del}(1 \mathrm{p})$ mutations [24]. The cytogenetic alternations have a great impact on the prognosis, drug resistance and median survival of MM [24]. The molecular categorization of $\mathrm{MM}$ is carried out based on the cytogenetic mutations observed in plasma cells through fluorescence in situ hybridization studies. Most MM patients were associated with trisomies of one or more odd-numbered chromosomes detected in malignant plasma cells. Meanwhile, approximately $30 \%$ of MM cases were characterized by the translocation of the immunoglobulin heavy chain ( $\mathrm{IgH}$ ) locus on chromosome $14[22,25,26]$. Both trisomies and $\mathrm{IgH}$ translocations were reported in about $15 \%$ of MM cases [26].

\section{Epigenetics of MM}

The expanding literature is supporting the role of epigenetic aberrations in MM initiation and progression. These aberrations are detected at the onset or during the evolvement of the disease $[22,27,28]$ and likely attributed to the significant variations in response to therapy and survival rates [29-31]. In addition to genetic alteration, the enduring research data indicate a potential role of epigenetic changes such as histone modification [22,32,33] and DNA methylation [34-37] in MM development. Mutations of specific epigenetic modifiers, including histone acetylation and histone methylation regulators, were reported in MM cases [38,39]. Intriguingly, epigenetic aberrations were found to regulate the expression of essential tumor suppressor miRNAs through hypermethylation [40-42]. Further, they seem to be the most critical underlying mechanism behind the dysregulation of miRNAs expression in MM [43-46]. On the other hand, miRNAs themselves can influence the epigenetic machinery by targeting their enzymatic modifiers and mediators [47]. For instance, miR-29b targets de novo methyltransferases mRNAs; thus, inhibiting DNA methylation in MM cells [48]. The epigenetic alterations further contributed to MM plasticity by enhancing the phenotypic diversity of MM cells and drug resistance [49,50].

DNA methylation is accomplished by adding a methyl group to the cytosine base, which can change the activity of DNA without changing its sequence. For instance, when methylation is present in a promoter region, it represses the expression of the gene. The methylation process is controlled by various enzymes such as DNA methyltransferases 1, 3A and 3B (DNMT1, DNMT3A and DNMT3B) in addition to the ten-eleven translocation (TET) protein family [51]. In MM, malignant cells are generally associated with DNA hypermethylation of tumor suppressor genes [51-57] and overall hypomethylation resulting in genomic instability [58,59], disease advancement [60], poor prognosis [34] and drug resistance [61]. Methylation of several tumor suppressor miRNAs such as miR-34 family, miR-194, miR-192 and miR-215 were identified in MM cases, which in turn resulted in their silencing [62-66].

Being an essential component of DNA chromatin, histone links the nucleosomes together and promotes the development of high ordered chromatin structures. The posttranslational modifications of the N-terminal tail of the histone protein affect gene transcription and DNA repair $[67,68]$. Therefore, aberrant posttranslational modifications of histones result in tumorigenesis [69]. Furthermore, the N-terminal tails are subject to methylation, acetylation and phosphorylation, impacting the gene transcription $[67,69,70]$. The emerging data are suggesting a critical role of histone posttranslational modifications in MM pathogenesis [71]. Altered posttranslational modifications were found to deregulate miRNAs in MM cells. For instance, miR-26 was down-regulated due to heterochromatin modification in $\mathrm{t}(4 ; 14)$ myeloma, which in turn led to enhanced MM cell proliferation [72]. 


\section{Diagnosis and Management of MM}

The diagnosis of MM depends mainly on both radiological and broad laboratory examinations. Symptoms revealed by MM patients are usually non-specific and of reduced value to confirm the diagnosis. Most of the MM cases presented with a history of anemia of unknown origin for an extended period. Additionally, they suffered from nausea, vomiting, generalized weakness, fatigue and weight loss [17]. Therefore, clinical examinations, in addition to extensive radiological and laboratory investigations, including complete blood count and cytogenic analysis, are crucial for an accurate diagnosis $[17,73]$. $\mathrm{MM}$ is commonly associated with monoclonal protein, abnormal immunoglobulin (Ig), production, including IgG and IgM [22]. Monoclonal protein can only be detected in around $82 \%$ of patients through serum protein electrophoresis [17]. However, performing the serum-free light chain assay or 24-h urinary protein electrophoresis with immunofixation increased the capacity of monoclonal protein detection [74]. It is worth mentioning that approximately $3 \%$ of MM patients have no reportable trace of monoclonal protein [75]. Abnormal monoclonal protein leads to blood hyperviscosity, end-organ failure, immunodeficiency in addition to cardiovascular and renal complications [22].

Unlike other malignancies, MM is characterized by osteolytic bone lesions, not bone growth. These invasive bone lesions result in severe bone aches, osteoporosis and pathologic fractures. Osteolytic bone lesions are critically helpful in the diagnosis of MM, as they are identified in about $80 \%$ of MM patients through magnetic resonance imaging and computerized tomography [76]. Further, bone marrow incursion by malignant plasma cells leads to anemia, immunosuppression and recurrent infections [77]. Bone marrow biopsy to detect clonal bone marrow plasma cells is essential for the diagnosis and staging of MM [17]. Other standard confirmatory tests include blood calcium and serum creatinine levels, which are often high in MM patients [17]. International Myeloma Working Group (IMWG) published diagnostic benchmarks for MM and its differential diagnosis, including Non-IgM MGUS, IgM MGUS, Light chain MGUS, SMM and solitary plasmacytoma (Figure 1) [11]. The diagnostic criteria depend primarily on the levels of serum or urinary monoclonal protein and the percentage of clonal bone marrow plasma cells. In addition, evidence of end-organ failure (CRAB criteria): hypercalcemia, renal insufficiency, anemia or bone lesions are fundamental for MM diagnosis. In 2014, the IMWG added three critical features to CRAB, which assisted in the early diagnosis and management of MM cases [11].

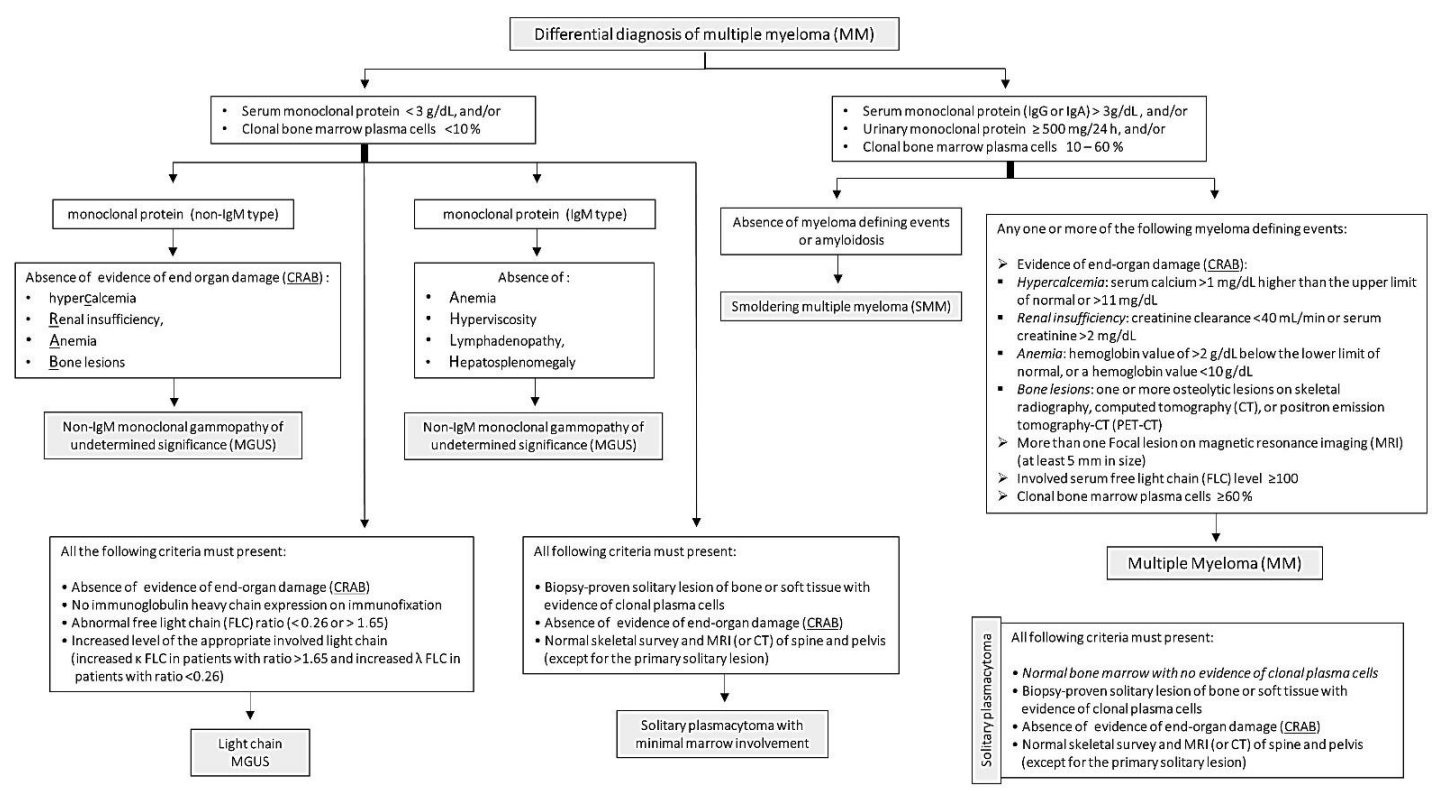

Figure 1. Diagnostic criteria of multiple myeloma and its differential diagnosis published by the International Myeloma Working Group. 
Management of MM patients depends on several factors, such as the stage, risk stratification, age and eligibility for transplantation therapy. In the case of low-risk patients, initial therapy includes four cycles of Velcade, Revlimid and Dexamethasone (VRD) followed by autologous stem-cell transplant (ASCT). However, in transplant-ineligible cases, patients continue 8 to 12 VRD cycles. Following the initial therapy, Lenalidomide and Bortezomib are commonly used as maintenance therapy. The initial therapy for high-risk patients comprises Kyprolis, Revlimid and Dexamethasone (KRD) followed by ASCT. Carfilzomib or Bortezomib are used for maintenance treatment [77].

\section{5. miRNA and Malignancy}

microRNA (miRNA) is a non-coding RNA molecule, 18 to 25 nucleotides in length [78,79]. miRNA constitutes roughly $1 \%$ of the human genome [80]. They are synthesized through several steps that include pre-miRNA transcription as well as post-transcriptional modifications through regulatory enzymes such as Drosha, Dicer, RNA-Induced Silencing Complex [79,81]. Although miRNAs do not code for protein, they were found to regulate protein synthesis through controlling messenger $(\mathrm{m}) \mathrm{RNA}$ transcription and translation, thus influencing various biological processes such as metabolism, cell proliferation and apoptosis [79,82]. Furthermore, miRNA is essential for negative feedback regulation of about $50 \%$ of the protein-coding genes. They control gene expression by direct binding to the $3^{\prime}$ untranslated region of mRNA, leading to its degradation or inhibition of its translation $[79,81]$.

miRNAs were shown to regulate the expression of genes controlling cancer development, e.g., oncogenes and tumor suppressor genes. Therefore, they possess a crucial role in the induction, evolution, propagation and metastasis of various malignancies [83]. miRNA may act as oncomiR or tumor suppressor miRNA if they target tumor suppressor genes or oncogenes, respectively [84]. OncomiRs are over-expressed in tumor cells while tumor suppressor miRNAs are usually down-regulated [85]. Thus, miRNA attracted global attention as possible therapeutic targets in cancer management [86].

Interestingly, the role of miRNA in malignancy exceeds the targeting of oncogenes or tumor suppressor genes to potentially form a cell-cell communication approach $[87,88]$ that affects various biological processes [89] at the receiving sites. This is achieved via the circulating miRNAs which are released from the production site in many forms either free or protein-bounded or stalked in membrane-bound vesicles such as extracellular vehicles (EVs) and exosomes. The process of transportation of circulating miRNAs is influenced by many extracellular factors, including plasma RNase, $\mathrm{pH}$, temperature and other digesting enzymes [90]. Circulating miRNAs could be either vesicle-associated $[91,92]$ or non-vesicle-associated, which are released in into the circulation in a protein-bounded form to protect them against plasma RNase [88,93-95].

\section{Role of miRNA in MM}

Several studies investigated the dysregulated miRNAs in MM plasma cells to identify the possible miRNAs involved in the MM pathogenesis and progression. Researchers used different approaches such as microarray, quantitative PCR and next-generation sequencing. The experimental samples included bone marrow clonal plasma cells, serum and urine were isolated from patients at various stages of the disease in addition to MM cell lines [96,97]. Interestingly, several miRNAs were dysregulated in $\mathrm{MM}$ and its asymptomatic pre-malignant stages. For instance, microarray analysis of samples obtained from both MGUS and MM patients revealed that miR-181a/b, miR-21 and miR-106b/25 were over-expressed in MGUS cases. Further, miR-181a/b, miR-32, miR-17-92, miR-21 and miR-106b/25 were up-regulated in both MM and MGUS patients. However, miR-32 and miR-17/92 were only detected only in MM patients, indicating the potential role of these miRNA in the evolution and transformation of MGUS to MM [98]. Being transported through exosomes, circulating miRNAs were found to contribute to the biogenesis and progression of MM, including tumor survival, proliferation [99,100], malignant transformation of the nearby normal cells [101]. Further, circulating miRNAs were found to enhance drug resistance, osteolysis and angiogenesis [102,103]. 
In addition to targeting oncogenes or tumor suppressor genes, miRNAs have been shown to have a significant impact on the various biological processes in MM cells, including proliferation, differentiation and angiogenesis in addition to the modulation of the bone marrow microenvironment. For instance, miRNAs can potentially regulate DNA methylation as previously discussed along with other crucial cellular pathways that control cellular proliferation, migration and apoptosis [104-108]. Additionally, miRNAs mediate substantial changes in the bone marrow microenvironment in MM patients. These changes include modulating bone marrow stromal cells to adhere to MM cells resulting in cytokine and growth factor secretion as well as activation of multiple genes and signaling pathways thus, enhancing tumor growth and drug resistance [109-112]. MM pathogenesis could generally be explained through interactions between MM cells and bone marrow stroma through circulating miRNAs, which was shown to preserve tumor load and enhance metastasis $[113,114]$. Furthermore, several miRNAs were found to enhance tumor growth by stimulating and augmenting the angiogenesis process through various mechanisms [115-117].

\subsection{OncomiRs and Their Therapeutic Potentials in MM}

Several miRNAs are up-regulated in MM to enhance tumor proliferation and growth (Table 1). Therefore, targeting these miRNAs showed remarkable anti-tumor activities. Thorough experiments and investigations revealed various mechanisms through which miRNAs could enhance MM growth and propagation. In this review, we discussed the different pathways targeted by miRNAs resulting in phenotypic and functional changes in addition to their potentials as therapeutic approaches.

\subsubsection{Modulation of the Bone Marrow Microenvironment}

MM growth requires a specific interaction between bone marrow stromal cells (BMSCs) and MM cells in the bone marrow to generate a favorable microenvironment for MM cell proliferation and survival. To sustain this environment, BMSCs release EVs that contain particular proteins and miRNAs. For example, miR-10a was over-expressed in EVs while it was down-regulated in BMSCs, suggesting that miR-10a was packaged into EVs and released into the bone marrow. Interestingly, inhibition of EV release led to the suppression of cell proliferation and the initiation of apoptosis in BMSCs. Moreover, the transfection of MM cells with miR-10a isolated from BMSCs improved their cell proliferation [118]. miR-181a was remarkably overexpressed in MM cells, where it regulates neuro-oncological ventral antigen-1 (NOVA1) expression. The silencing of miR-181a resulted in a substantial promotion of cellular apoptosis. Furthermore, miR-181a inhibitor reduced the expression of NOVA1 and inhibited tumor growth in vivo. Consistently, miR-181 mimics induced opposite effects [119].

Bone marrow clonal plasma cells were found to up-regulate both miR-27b-3p and miR-214-3p in fibroblasts through the release of exosomes containing WW and C2 Domain Containing 2 (WWC2) protein that enhances the transition of MGUS to MM. This further emphasizes the role of malignant plasma cells in modifying the bone marrow microenvironment by reprogramming fibroblasts' behavior [120]. Interleukin (IL)-17 producing CD4+ T cells (Th17) are essential for MM growth and bone injury associated with osteoclast activity. Excitingly, inhibition of miR-21 in naive T cells suppressed Th17 differentiation in vitro, thus impairing tumor growth. Mechanistically, blocking of miR-21 resulted in the up-regulation of Signal transducer and activator of transcription (STAT)-1/-5a-5b and impairment of STAT3 pathways [121].

\subsubsection{Enhancing Cellular Proliferation and Tumor Growth}

Over-expression of miR-27b-3p and miR-214-3p induced proliferation and apoptosis resistance in MM fibroblasts through activation of F-box and WD repeat domain containing 7 (FBXW7) and Phosphatase and tensin homolog (PTEN)/protein kinase B (AKT)/Glycogen synthase kinase (GSK)3 pathways. Consistently, transfection of miR-27b-3p and miR-214-3p inhibitors resulted in suppressing the anti-apoptotic factors, induced myeloid leukemia cell differentiation protein MCL1 [120]. 
miR-221/222 were found to down-regulate other tumor suppressor genes in MM [122]. miR-221/222 were highly expressed in specific subgroups of MM, and its down-regulation led to inhibition of MM growth in both in vitro and in vivo [123]. In addition, miR-221/222 activates the following pathways: p27Kip1, p57Kip2, PTEN and p53 up-regulated modulator of apoptosis (PUMA) [123]. miR-21 was found to be vital for MM growth and development through activation of pro-survival signaling and targeting tumor suppressor genes such as Ras homolog (Rho)-B and PTEN. Furthermore, anti-miR-21 triggered an over-expression of the previously mentioned tumor suppressor genes [124].

\subsubsection{Promoting Cell Migration and Metastasis}

Over-expression of miR125a-5p was observed in MM cells [125]. Remarkably, anti-miR-125a-5p significantly reduced cell migration and proliferation in addition to enhancing cellular apoptosis through p53 pathway activation [126]. In MM cells, miR-21 transcription was not regulated by IL-6. As a result, the dysregulated miR-21 enhanced the malignant transformation of plasma cells [97]. miR-19b and miR-20a are crucial oncomiRs that are up-regulated in MM plasma cells. miR-19b/20a enhanced cell proliferation and migration as well as inhibited cell apoptosis in MM. Transfection of miR-19b/20a resulted in the down-regulation of PTEN protein (a tumor suppressor protein with anti-proliferation and pro-apoptosis effects). Lentivirus-mediated delivery of miR-20a boosted tumor growth; therefore, it may resemble a potential therapeutic target [127]. miR-27 was overexpressed in MM cases when compared with control, which was associated with shorter overall survival. miR-27 mimics boosted cell proliferation, migration and invasion through targeting Sprouty homolog 2 (SPRY2). Meanwhile, anti-miR-27 resulted in contrasting effects. miR-27 inhibition showed anti-tumor effects on MM cells [128].

\subsubsection{Boosting Cell Viability and Inhibiting Apoptosis}

Researchers reported that miR-106b, miR-25 and miR-93 were over-expressed in MGUS and $\mathrm{MM}$ cases [98]. Intriguingly, anti-miR-106b/25 reduced the cell viability and induced apoptosis in MM plasma cells by inhibiting p38/mitogen-activated protein kinase (MAPK) dependent signaling pathway [129]. Similarly, miR-19b/20a inhibited cell apoptosis MM cells through targeting PTEN pathway [127]. Furthermore, miR-214-3p increased resistance against apoptosis through targeting the apoptotic FBXW7 and PTEN/AKT/GSK3 pathways [120].

\subsubsection{Fostering Drug Resistance}

miR-221/222 was over-expressed in plasma cells of MM patients and was found to mediate inhibition of autophagy, which in turn promotes dexamethasone resistance. miR-221/222 targeted autophagy-related gene 12 (ATG12) and p27kip (p27)-mammalian target of rapamycin (mTOR) pathway to reduce autophagy. In fact, Dexamethasone treatment reduced the expression of miR-221/222, thus stimulating ATG12/p27-mTOR pathways and inducing cell apoptosis [130]. 
Table 1. miRNAs acting as oncomiRs in multiple myeloma (MM) and their potential targets.

\begin{tabular}{|c|c|c|c|}
\hline miRNA & Mechanisms of Action & Targets & Reference \\
\hline miR-10a & $\begin{array}{c}\uparrow \text { cell proliferation } \\
\downarrow \text { apoptosis }\end{array}$ & - & [118] \\
\hline $\operatorname{miR}-19 b$ & $\begin{array}{c}\uparrow \text { cell proliferation and migration } \\
\downarrow \text { apoptosis }\end{array}$ & PTEN protein & [127] \\
\hline $\operatorname{miR}-20 \mathrm{a}$ & $\begin{array}{c}\uparrow \text { cell proliferation and migration } \\
\downarrow \text { apoptosis }\end{array}$ & PTEN protein & [127] \\
\hline miR-21 & $\begin{array}{c}\downarrow \mathrm{CD} 4+\mathrm{T} \text { cells (Th17) differentiation } \\
\uparrow \text { pro-survival signaling }\end{array}$ & $\begin{array}{l}\text { STAT- } 1 /-5 a-5 b \text { and STAT3 } \\
\text { Rho-B and PTEN }\end{array}$ & $\begin{array}{l}{[121]} \\
{[124]}\end{array}$ \\
\hline miR-25 & $\begin{array}{l}\uparrow \text { cell viability } \\
\downarrow \text { apoptosis }\end{array}$ & p38/MAPK & [129] \\
\hline miR-27 & $\uparrow$ cell proliferation, migration and invasion & SPRY2 & [128] \\
\hline miR-27b-3p & $\uparrow$ proliferation and apoptosis resistance & FBXW7 and PTEN/AKT/GSK3 & [120] \\
\hline miR-93 & $\begin{array}{l}\uparrow \text { cell viability } \\
\downarrow \text { apoptosis }\end{array}$ & p38/MAPK & [129] \\
\hline miR-106b & $\begin{array}{l}\uparrow \text { cell viability } \\
\downarrow \text { apoptosis }\end{array}$ & p38/MAPK & [129] \\
\hline miR-181a & $\downarrow$ apoptosis & NOVA1 & [119] \\
\hline miR-125a-5p & $\begin{array}{c}\uparrow \text { cell proliferation and migration } \\
\downarrow \text { apoptosis }\end{array}$ & - & {$[125,126]$} \\
\hline miR-214-3p & $\uparrow$ proliferation and apoptosis resistance & FBXW7 and PTEN/AKT/GSK3 & [120] \\
\hline $\operatorname{miR}-221$ & $\begin{array}{c}\downarrow \text { autophagy } \\
\uparrow \text { Dexamethasone resistance } \\
\uparrow \text { tumor growth }\end{array}$ & $\begin{array}{c}\text { ATG12 and p27/mTOR } \\
\text { p27/Kip1, p57Kip2, PTEN and PUMA }\end{array}$ & $\begin{array}{l}{[130]} \\
{[123]}\end{array}$ \\
\hline $\operatorname{miR}-222$ & $\begin{array}{c}\downarrow \text { autophagy } \\
\uparrow \text { Dexamethasone resistance } \\
\uparrow \text { tumor growth }\end{array}$ & $\begin{array}{c}\text { ATG12 and p27/mTOR } \\
\text { p27/Kip1, p57/Kip2, PTEN and PUMA }\end{array}$ & $\begin{array}{l}{[130]} \\
{[123]}\end{array}$ \\
\hline
\end{tabular}

\subsection{Tumor Suppressor miRNAs and Their Therapeutic Potentials in MM}

Multiple studies found several miRNAs to be down-regulated in MM plasma cells. These miRNAs possess a pivotal role in the suppression of tumor growth through various pathways (Table 2). Tumor suppressor miRNAs act via inhibiting essential oncogenes, among other mechanisms, to reduce tumor growth.

\subsubsection{Inhibiting Cellular Proliferation, Cell Cycle and Tumor Growth}

miR-26a was down-regulated in MM plasma cells. Alternatively, induced overexpression of miR-26a reduced proliferation and migration as well as prompted apoptosis in MM cell lines. CD38 protein was found to be targeted and down-regulated by miR-26a. Therefore, CD38 protein was indicated to be responsible for the activation of cell proliferation and the restriction of cell apoptosis. As a result, Daratumumab, the first anti-CD38 drug, was developed as a monotherapy and in combination with other drugs to treat MM cases [131]. miR-29b expression was significantly reduced in MM cells. Thereby, ectopic up-regulation of miR-29b hindered cell proliferation and prompted cycle arrest in malignant plasma cells. miR-29b was shown to target the Forkhead box protein P1 (FOXP1) pathway to induce its effects. The restoration of FOXP1 diminished miR-29b-induced pro-apoptosis and anti-proliferation activities [132]. The expression of miR-489 was significantly reduced in MM cell lines. miR-489 acts as a tumor suppressor gene through reducing cell proliferation and viability of MM cells. Additionally, miR-489 inhibited glucose uptake, thus ATP production. Lactate dehydrogenase-A (LDHA) was identified as a potential target of miR-489. Taken together, a reduction in ATP production 
and cell proliferation through targeting LDHA was responsible for the inhibitory effects of miR-489 on MM cells [133].

\subsubsection{Enhancing Apoptosis and Decreasing Cell Viability}

miR-155 expression was significantly reduced in MM cases, thus indicating a tumor suppressor role. miR-155 replacement induced pro-apoptotic and anti-proliferative effects in the MM cell line [134]. Mitochondrial RNA processing endoribonuclease (RMRP) was up-regulated, whereas miR-34a-5p was down-regulated in MM cell lines. Over-expression of RMRP expression enhanced cell proliferation of MM cell lines. Consistently, RMRP knockdown induced apoptosis in the same cells. The silencing of miR-34a-5p was associated with high RMRP levels. Moreover, high expression of miR-34a-5p inhibited proliferation and fostered apoptosis, which indicates that RMRP acts as a miR-34a-5p MASK to boost cell proliferation and suppress cell apoptosis [135]. miR-15a and miR-16-1 were down-regulated in MM cases. Furthermore, malignant plasma cells transfected with miR-15a/16-1 showed cellular apoptosis and repressed tumor growth. Both miR-15a and miR-16-1 were found to inhibit tumor survival pathways, including mitogen-activated protein (MAP)-kinases, AKT serine/threonine-protein-kinase, NF-KB-activator MAP3KIP3 and ribosomal-protein-S6 [136].

Similarly, miR-125b was down-regulated in MM patients [137] by cancer-secreted growth factors such as tumor necrosis factor (TNF) and insulin growth factor (IGF)-1 [138,139]. Restoration of miR-125b through the replacement approach showed a remarkable inhibitory effect on malignant plasma cells, which was achieved by repressing interferon regulatory factor (IRF) 4 addiction, which is essential for MM growth and development $[138,139]$. Interestingly, miR-125b was found to up-regulate miR-34a, which in turn inhibits the IL-6 receptor/STAT3/miR-34a feedback loop. As a result, these pathways activate cell death machinery in MM [140]. The up-regulation of miR-33b resulted in significant apoptosis of malignant plasma cells, thus suppressing cancer growth and enhancing survival rates [141]. Interestingly, miR-33b targeted a serin/threonine kinase known as PIM-1, which blocks the linkage between BCL2 associated agonist of cell death (Bad) and Bcl2/l-xl to inhibit apoptosis [141]. $\mathrm{p} 53$, a potent tumor suppressor gene, was found to have a critical role in protecting against MM development. Several miRNAs were reported to be engaged in regulating p53 during the disease, such as miR-194-2/192 and miR-215/194-1 families [142].

miR-34a mimics inhibited tumor growth in MM mice models through activation of apoptotic pathways and suppression of pro-survival signaling, including cell division protein kinase (CDK)6, BCL2 and NOTCH1 [143]. Additionally, miR-34a was found to reduced plasma cell proliferation by repressing transforming growth interaction factor 2 (TGIF2) [144]. Similarly, miR-29b mimics down-regulated proliferative and anti-apoptotic pathways in MM cells such as MCL-1, CDK6 and SP1 [145] in addition to other epigenetic regulators [146] including DNA methyltransferase three alpha/beta (DNMT3A/B) [147] and Histone Deacetylase 4 (HDAC4) [148]. Additionally, mir-29b increased the MM sensitivity towards Bortezomib [145,149].

\subsubsection{Increasing Sensitivity to Drugs}

miR-155 was down-regulated in Bortezomib-resistant MM patients suggesting a possible role of miR-155 in Bortezomib resistance. miR-155 replacement augmented Bortezomib therapeutic efficacy. Researchers suggested that the anti-tumor properties of miR-155 were attributed to inhibiting proteasome subunit gene, PSM $\beta 5$ [134]. miR-192/215/194 were found to be down-regulated in MM cases [150]. The expression of these miRNAs was usually accompanied by an activation of the p53 pathway, which is associated with low Mouse double minute (MDM)2 levels. Consistently, the replacement of miR-192, miR-215 and miR-194 augmented the therapeutic efficacy of MDM2 inhibitors through enhancing p53 pathway [150]. miR-214 inhibits p28/gankyrin, which are oncogenes that suppress 53 by binding to the MDM2/HDM2 complex. Therefore, miR214 replacement improves p53 signaling by blocking gankyrin oncoproteins [151]. The expression of miR-520g/520h was significantly low in Bortezomib-resistant MM cell lines. Moreover, the up-regulation of miR-520g 
and miR-520h impeded cell viability and the expression of the homologous recombination-related protein (Rad51) in Bortezomib-resistant MM cells by targeting Apurinic/apyrimidinic endonuclease (APE)1 in vitro, in addition to repressing tumor growth in vivo [152].

\subsubsection{Hindering Survival and Genomic Instability}

Activation of DNA ligase III (LIG3) is critical for the survival and genomic inconsistency of MM cells. The up-regulation of LIG3 mRNA is associated with more advanced MM and shorter survival. Interestingly, miR-22-3p was identified as an efficient inhibitor of LIG3, which, in turn, enhanced DNA damage in MM cells [153]. miR-125a was down-regulated in MM cell lines. It functions as a tumor suppressor gene by reducing cell viability and colony-forming activity. miR-125a targets ubiquitin-specific peptidase 5 (USP5) mRNA, an oncoprotein that enhances cellular deubiquitination and proteolysis. Highly expressed miR-125a significantly repressed tumor growth of $\mathrm{MM}$ and lowered USP5 expression in vivo [154]. miR-101-3p was down-regulated and survivin (BIRC5) was up-regulated in MM cells. Notably, miR-101-3p was found to target and down-regulate survivin, which reduces the cell viability of malignant plasma cells. Moreover, anti-miR-101-3p was associated with a high expression of survivin [155]. miR-155 was down-regulated in drug-resistant MM through regulating CD47. Up-regulation of miR-155 inhibited CD47 expression on the plasma cell surface, thereby promoting phagocytosis of MM cells by macrophages. Moreover, miR-155 enhanced the sensitivity of drug-resistant MM cells to Bortezomib through targeting Tumor Necrosis Factor Alpha Induced Protein 8 (TNFAIP8), an oncoprotein which negatively inhibits apoptosis [156].

\subsubsection{Blocking Angiogenesis}

Angiogenesis is exceptionally critical for tumor growth in MM [157]. Several miRNAs were involved in the regulation of endothelial cells proliferation and new blood vessel formation. For instance, the replacement of miR-15a/16 inhibited vascular endothelial growth factor (VEGF) expression, thus suppressing the capillary formation and tumor growth [158]. miR-199a-5p down-regulated the gene expression of angiogenic factors such as VEGF-A, hypoxia-inducible factors (HIF)- $1 \alpha$, IL-8 and fibroblast growth factor (FGF)-b [116]. Moreover, miR-199a-5p was shown to regulate invasion and metastasis of MM [159]. Administration of miR-199a-5p mimic was proven to inhibit malignant cells' chemotaxis pathways, including metalloproteinase (MMP)2, Vascular cell adhesion protein (VCAM)-1, Discoidin domain receptor (DDR)1 and Intercellular Adhesion Molecule (ICAM)-1 [116]. Other pathways for cellular migration incorporate Wnt pathway and its regulatory factors, e.g., B-cell CLL/lymphoma (BCL)9 and $\beta$-catenin [160]. Intriguingly, miR-30-5p impeded proliferation and migration of MM plasma cells through inhibiting the BCL9 pathway [160]. 
Table 2. miRNAs acting as tumor suppressor genes in MM and their potential targets.

\begin{tabular}{|c|c|c|c|}
\hline miRNA & Mechanisms of Action & Targets & Reference \\
\hline \multirow[b]{2}{*}{$\begin{array}{l}\text { miR-15a, } \\
\text { miR-16 }\end{array}$} & $\downarrow$ capillary formation, tumor growth & VEGF & [158] \\
\hline & $\uparrow$ apoptosis & $\begin{array}{c}\text { MAP-kinases, AKT } \\
\text { serine/threonine-protein-kinase, } \\
\text { NF-kB-activator MAP3KIP3 and } \\
\text { ribosomal-protein-S6 }\end{array}$ & [136] \\
\hline miR-22-3p & $\downarrow$ survival, genomic instability & DNA ligase III & [153] \\
\hline \multirow{2}{*}{ miR-26a } & $\downarrow$ cell proliferation, migration & \multirow{2}{*}{ CD38 } & \multirow{2}{*}{ [131] } \\
\hline & $\uparrow$ apoptosis & & \\
\hline \multirow{5}{*}{$\mathrm{miR}-29 \mathrm{~b}$} & $\uparrow$ apoptosis & MCL-1, CDK6 and SP1 & [145] \\
\hline & $\downarrow$ cell proliferation & DNMT3A/B and HDAC4 & {$[147,148]$} \\
\hline & $\uparrow$ sensitivity to Bortezomib & MCL-1, CDK6 and SP1 & {$[145,149]$} \\
\hline & $\downarrow$ cell proliferation & \multirow{2}{*}{ FOXP1 } & \multirow{2}{*}{ [132] } \\
\hline & $\uparrow$ cell cycle arrest & & \\
\hline miR-30-5p & $\downarrow$ cell proliferation, migration & BCL9 & [160] \\
\hline \multirow{2}{*}{$\mathrm{miR}-33 \mathrm{~b}$} & $\downarrow$ linkage between Bad and Bcl2/l-xl & \multirow{2}{*}{ PIM-1 } & \multirow{2}{*}{ [141] } \\
\hline & $\uparrow$ apoptosis & & \\
\hline \multirow{3}{*}{ miR-34a } & $\downarrow$ tumor growth & IL-6 receptor/ STAT3 & [140] \\
\hline & $\uparrow$ apoptosis & \multirow{2}{*}{ CDK6, BCL2 and NOTCH1 } & \multirow{2}{*}{ [143] } \\
\hline & $\downarrow$ pro-survival signaling & & \\
\hline \multirow{2}{*}{ miR-34a-5p } & $\downarrow$ proliferation & \multirow{2}{*}{ RMRP } & \multirow{2}{*}{ [135] } \\
\hline & $\uparrow$ apoptosis & & \\
\hline miR-101-3p & $\downarrow$ cell viability & survivin (BIRC5) & [155] \\
\hline miR-125a & $\downarrow$ cell viability, colony-forming activity & USP5 & [154] \\
\hline miR-125b & $\downarrow$ tumor growth & IRF4 & {$[138,139]$} \\
\hline \multirow{4}{*}{ miR-155 } & $\uparrow$ pro-apoptotic, anti-proliferative effects & \multirow{2}{*}{ proteasome subunit gene, PSM $\beta 5$} & \multirow{2}{*}{ [134] } \\
\hline & $\uparrow$ Bortezomib therapeutic sensitivity & & \\
\hline & $\uparrow$ phagocytosis of MM cells by macrophages & $\mathrm{CD} 47$ & [156] \\
\hline & $\uparrow$ sensitivity of drug-resistant MM cells to Bortezomib & TNFAIP8 & [156] \\
\hline miR-192 & $\downarrow$ cell proliferation & TGIF2 & [144] \\
\hline $\begin{array}{l}\text { miR-192, } \\
\text { miR-194, } \\
\text { miR-215 }\end{array}$ & Augmented the therapeutic efficacy of MDM2 inhibitors & p53 and MDM2 & [150] \\
\hline \multirow{2}{*}{ miR-199a-5p } & $\downarrow$ capillary formation, tumor growth & VEGF-A, HIF- $1 \alpha$, IL- 8 and FGFb & [116] \\
\hline & $\downarrow$ plasma cells chemotaxis & MMP2, VCAM-1, DDR1 and ICAM-1 & [116] \\
\hline miR-214 & $\downarrow$ tumor growth & p53 and p28/gankyrin & [151] \\
\hline \multirow{2}{*}{$\operatorname{miR}-489$} & $\downarrow$ cell proliferation, viability & \multirow{2}{*}{ LDHA } & \multirow{2}{*}{ [133] } \\
\hline & $\downarrow$ glucose uptake, ATP production & & \\
\hline miR-520g,h & $\downarrow$ cell viability & Rad51 and APE1 & [152] \\
\hline
\end{tabular}

\footnotetext{
$\uparrow$ increase; $\downarrow$ decrease.
}

\section{7. miRNAs Therapeutic Strategies in MM}

Being involved in the development and the evolution of MM, miRNAs could represent potential therapeutic targets. Two strategies are currently being investigated: inhibition of up-regulated oncomiRs and replacement of down-regulated tumor suppressor miRNAs. Some of the challenges in miRNA therapeutic strategies include miRNA stability, selective cellular uptake by target cells through an effective delivery system, possible off-target and unwanted toxicities and the activation of innate immune responses [161,162]. 


\subsection{Inhibition of oncomiRs}

On the other hand, specific miRNAs are up-regulated in MM to enhance proliferation, growth and migration of malignant cells. Consequently, scientists are currently developing several approaches to target these miRNAs. For instance, antisense miRNA inhibitors (antagomirs) bind exclusively to the sense miRNA resulting in its inhibition [163]. Moreover, locked nucleic acid linked to a phosphorothioate backbone is commonly used to augment the stability and affinity of antagomirs to their target miRNAs $[164,165]$. Other approaches include miRNA sponges, which are transcripts that have several binding sites that preclude binding sites of the oncomiRs to mRNA [166]. Similarly, MASK, a synthesized oligonucleotide complementary to the binding sites of miRNA, blocks its interaction with mRNA [167].

miR-17-92 cluster is a polycistron encoding 6 miRNAs (miR-17, miR-18a, miR-19a, miR-19b-1, miR-20a and miR-92-1) confer tumorigenicity in MM, regulated by c-Myc, an oncogenic transcription factor [168]. The miR-17-92 cluster is encoded by MIR17HG at 13q31.3 [169]. MIR17PTi is a novel locked nucleic acids gapmeR antisense oligonucleotide to induce degradation of MIR17HG primary transcripts (pri-mir-17-92) and thus resulted in the down-regulation of miR-17-92 miRNAs [170]. Furthermore, MIR17PTi treatment was reported to inhibit malignant plasma cell proliferation and stimulate cellular apoptosis, suggesting the potential of pri-miRNA therapeutics in cancer therapy [170].

\subsection{Replacement of Tumor Suppressor miRNAs}

Some of the miRNAs that are down-regulated in different categories of MM may have potential inhibitory effects on tumor growth and metastasis. Therefore, identification of these miRNAs and their biological functions may help to develop powerful therapeutic tools through suppression of pro-survival conditions and progression of MM. One such example is miR-34a, which is known to act as a tumor suppressor in numerous cancers. In fact, MRX34, a liposomal miR-34a mimic, is the first human phase I clinical trial of miRNA cancer therapy in all patients with advanced solid tumors [171]. Although the trial was closed early due to serious immune-mediated adverse effects that resulted in the death of four patients, the dose-dependent modulation of relevant target genes provides proof-of-concept for miRNA-based cancer therapy [172]. The combination treatment with miR-34a has been shown to enhance the anti-tumor activity of other anti-cancer agents $(\gamma$-secretase inhibitor, sirtinol and zoledronic acid) in MM cells, through various mechanisms [173]. The $\gamma$-secretase inhibitor enhanced miR-34a-dependent anti-tumor effects by activating an extrinsic apoptotic pathway, whereas the combination of miR-34a and sirtinol, induced the activation of an intrinsic apoptotic pathway [173].

To replace the down-regulated miRNAs, different tools, including viral vectors, non-viral vectors (inorganic compounds and lipid-based carries) and miRNAs mimics can be used [174,175]. However, most MM cells are transfection-resistant. A non-viral nanoparticulate transfection system, poly(glycidol)-based nanogels with covalently bound cell-penetrating peptide TAT (transactivator of transcription) has shown to efficiently delivered and released miR-34a into transfection-resistant OPM-2 MM cells [176]. The delivery of miR-34a resulted in significant down-regulation of known target genes (Notch1, Hey1, Hes6 and Hes1), suggesting the nanogel constructs offer a new tool to enhance gene delivery [176].

\section{Circulating miRNAs as Biomarkers for MM Diagnosis}

Since miRNAs have been found in body fluids such as plasma, serum, saliva, urine and semen, circulating miRNAs have been proposed as novel disease biomarkers that may aid in diagnosis, prognosis and monitoring of treatment response [177-180]. The circulating miRNAs were stable when refrigerated or frozen for up to $72 \mathrm{~h}$ and at room temperature for $24 \mathrm{~h}$, making them suitable biomarkers [181,182]. 
Serum analysis revealed a combination of up-regulated miR-34a and down-regulated let-7e could distinguish MM from control with a sensitivity and specificity of $80 \%$, and MGUS with a sensitivity and specificity of over $90 \%$ (Table 3) [183]. Other suggested markers include increased plasma miR-125b-5p, serum miR-29a, serum miR-4449, and decreased serum miR-30d and miR-203 levels [184-188]. In addition, the miR-125b-5p level was associated with extramedullary infiltration and was significantly higher in stage III patients compared to stage I/II patients [184]. Similarly, plasma miR-483-5p level in MM patients was also found to be correlated with ISS stage [189].

Table 3. miRNAs acting as diagnostic markers in MM.

\begin{tabular}{cccccc}
\hline Sample & miRNAs & Expression Changes in MM Patients & Sensitivity & Specificity & Reference \\
\hline \multirow{3}{*}{ Plasma } & miR-34a & $\uparrow$ & $81 \%$ & $87 \%$ & {$[183]$} \\
& let-7e & $\downarrow$ & $86 \%$ & $96 \%$ & \\
& miR-125b-5p & $\uparrow$ & $60 \%$ & $85 \%$ & {$[184]$} \\
\hline \multirow{5}{*}{ Serum $-490-3 p$} & $\uparrow$ & $\uparrow$ & $88 \%$ & $70 \%$ & {$[185]$} \\
& miR-29a & $\uparrow$ & $83 \%$ & $83 \%$ & {$[186]$} \\
& miR-203 & $\downarrow$ & $79 \%$ & $91 \%$ & {$[187]$} \\
& miR-4449 & $\uparrow$ & $89 \%$ & $63 \%$ & {$[188]$} \\
& miR-48d & $\downarrow$ & $58 \%$ & $90 \%$ & {$[189]$} \\
\hline
\end{tabular}

$\uparrow$ increase; $\downarrow$ decrease.

Apart from being a diagnostic marker, numerous mRNAs have been suggested for diagnosis of survival prediction in MM patients. Low levels of serum miR-744 and let-7e were associated with shorter overall survival and remission of MM patients [183], while high levels of plasma miR-483-5p, serum miRNA-720 and miRNA-1246 were associated with shorter progression-free survival, indicating poor prognosis $[189,190]$.

\section{Conclusions}

This review summarized various miRNAs with the role of tumor suppressor and oncomiR in MM. In addition, miRNAs are also involved in treatment resistance in MM patients. Currently, the full complement of miRNAs involved in the pathogenesis of MM has yet to be fully elucidated. Further studies on miRNA dysregulation in MM may provide novel sensitive diagnostic markers, therapeutic options for $\mathrm{MM}$, as well as to resolve treatment resistance in patients.

Author Contributions: Conceptualization, S.D.; writing—original draft preparation, A.M.S., T.S.L.; writing—review and editing, P.M., S.D. All authors have read and agreed to the published version of the manuscript.

Funding: This research received no external funding.

Conflicts of Interest: The authors declare no conflict of interest. 


\section{Abbreviations}

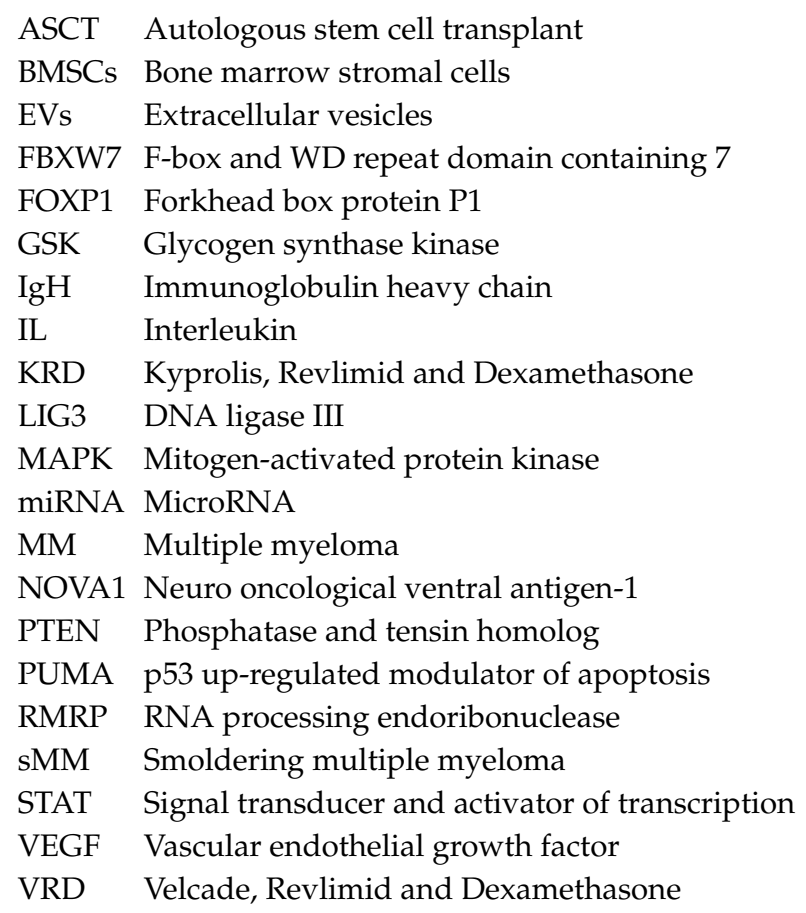

\section{References}

1. Kazandjian, D.; Mailankody, S.; Korde, N.; Landgren, O. Smoldering multiple myeloma: Pathophysiologic insights, novel diagnostics, clinical risk models, and treatment strategies. Clin. Adv. Hematol. Oncol. 2014, 12, 578-587. [PubMed]

2. Low, S.F.; Mohd Tap, N.H.; Kew, T.Y.; Ngiu, C.S.; Sridharan, R. Non secretory multiple myeloma with extensive extramedullary plasmacytoma: A diagnostic dilemma. Iran. J. Radiol. 2015, 12, e11760. [CrossRef] [PubMed]

3. Bakheet, O.S.E.; Leong, C.F.; Ithnin, A.; Wahid, S.F.A. IgD-kappa multiple myeloma. Case report and brief review of the literature. N. Z. J. Med. Lab. Sci. 2016, 70, 8-11.

4. Landgren, O.; Kyle, R.A.; Pfeiffer, R.M.; Katzmann, J.A.; Caporaso, N.E.; Hayes, R.B.; Dispenzieri, A.; Kumar, S.; Clark, R.J.; Baris, D.; et al. Monoclonal gammopathy of undetermined significance (MGUS) consistently precedes multiple myeloma: A prospective study. Blood 2009, 113, 5412-5417. [CrossRef]

5. Weiss, B.M.; Abadie, J.; Verma, P.K.; Howard, R.S.; Kuehl, W.M. A monoclonal gammopathy precedes multiple myeloma in most patients. Blood 2009, 113, 5418-5422. [CrossRef]

6. Kyle, R.A.; Therneau, T.M.; Rajkumar, S.V.; Larson, D.R.; Plevak, M.F.; Offord, J.R.; Dispenzieri, A.; Katzmann, J.A.; Melton, L.J., III. Prevalence of monoclonal gammopathy of undetermined significance. N. Engl. J. Med. 2006, 354, 1362-1369. [CrossRef]

7. Kyle, R.A.; Therneau, T.M.; Rajkumar, S.V.; Offord, J.R.; Larson, D.R.; Plevak, M.F.; Melton, L.J., III. A long-term study of prognosis in monoclonal gammopathy of undetermined significance. N. Engl. J. Med. 2002, 346, 564-569. [CrossRef]

8. Dispenzieri, A.; Katzmann, J.A.; Kyle, R.A.; Larson, D.R.; Melton, L.J., III; Colby, C.L.; Therneau, T.M.; Clark, R.; Kumar, S.K.; Bradwell, A.; et al. Prevalence and risk of progression of light-chain monoclonal gammopathy of undetermined significance: A retrospective population-based cohort study. Lancet 2010, 375, 1721-1728. [CrossRef]

9. Kyle, R.A.; Remstein, E.D.; Therneau, T.M.; Dispenzieri, A.; Kurtin, P.J.; Hodnefield, J.M.; Larson, D.R.; Plevak, M.F.; Jelinek, D.F.; Fonseca, R.; et al. Clinical course and prognosis of smoldering (asymptomatic) multiple myeloma. N. Engl. J. Med. 2007, 356, 2582-2590. [CrossRef] 
10. Rajkumar, S.V.; Gupta, V.; Fonseca, R.; Dispenzieri, A.; Gonsalves, W.I.; Larson, D.; Ketterling, R.P.; Lust, J.A.; Kyle, R.A.; Kumar, S.K. Impact of primary molecular cytogenetic abnormalities and risk of progression in smoldering multiple myeloma. Leukemia 2013, 27, 1738-1744. [CrossRef]

11. Rajkumar, S.V.; Dimopoulos, M.A.; Palumbo, A.; Blade, J.; Merlini, G.; Mateos, M.V.; Kumar, S.; Hillengass, J.; Kastritis, E.; Richardson, P.; et al. International Myeloma Working Group updated criteria for the diagnosis of multiple myeloma. Lancet Oncol. 2014, 15, e538-e548. [CrossRef]

12. Rajkumar, S.V. Multiple myeloma: 2014 Update on diagnosis, risk-stratification, and management. Am. J. Hematol. 2014, 89, 998-1009.

13. Siegel, R.L.; Miller, K.D.; Jemal, A. Cancer statistics, 2016. CA Cancer J. Clin. 2016, 66, 7-30. [CrossRef] [PubMed]

14. Phekoo, K.J.; Schey, S.A.; Richards, M.A.; Bevan, D.H.; Bell, S.; Gillett, D.; Møller, H.; Consultant Haematologists; South Thames Haematology Specialist Committee. A population study to define the incidence and survival of multiple myeloma in a National Health Service Region in UK. Br. J. Haematol. 2004, 127, 299-304. [CrossRef] [PubMed]

15. Visser, O.; Trama, A.; Maynadié, M.; Stiller, C.; Marcos-Gragera, R.; De Angelis, R.; Mallone, S.; Tereanu, C.; Allemani, C.; Ricardi, U.; et al. Working Group. Incidence, survival and prevalence of myeloid malignancies in Europe. Eur. J. Cancer 2012, 48, 3257-3266. [CrossRef]

16. Ruzafa, J.C.; Merinopoulou, E.; Baggaley, R.F.; Leighton, P.; Werther, W.; Felici, D.; Cox, A. Patient population with multiple myeloma and transitions across different lines of therapy in the USA: An epidemiologic model. Pharm. Drug Saf. 2016, 25, 871-879. [CrossRef]

17. Kyle, R.A.; Gertz, M.A.; Witzig, T.E.; Lust, J.A.; Lacy, M.Q.; Dispenzieri, A.; Fonseca, R.; Rajkumar, S.V.; Offord, J.R.; Larson, D.R.; et al. Review of 1027 patients with newly diagnosed multiple myeloma. Mayo Clin. Proc. 2003, 78, 21-33. [CrossRef]

18. Waxman, A.J.; Mink, P.J.; Devesa, S.S.; Anderson, W.F.; Weiss, B.M.; Kristinsson, S.Y.; McGlynn, K.A.; Landgren, O. Racial disparities in incidence and outcome in multiple myeloma: A population-based study. Blood 2010, 116, 5501-5506. [CrossRef]

19. Munshi, N.C. Plasma cell disorders: An historical perspective. Ash Educ. Program. Book 2008, $2008,297$. [CrossRef]

20. Giuliani, N.; Rizzoli, V.; Roodman, G.D. Multiple myeloma bone disease: Pathophysiology of osteoblast inhibition. Blood 2006, 108, 3992-3996. [CrossRef]

21. Rajkumar, S.V. Multiple myeloma: 2016 update on diagnosis, risk-stratification, and management. Am. J. Hematol. 2016, 91, 719-734. [PubMed]

22. Kuehl, W.M.; Bergsagel, P.L. Multiple myeloma: Evolving genetic events and host interactions. Nat. Rev. Cancer 2002, 2, 175-187. [PubMed]

23. Bianchi, G.; Anderson, K.C. Understanding biology to tackle the disease: Multiple myeloma from bench to bedside, and back. CA Cancer J. Clin. 2014, 64, 422-444. [PubMed]

24. Rajan, A.M.; Rajkumar, S.V. Interpretation of cytogenetic results in multiple myeloma for clinical practice. Blood Cancer J. 2015, 5, e365. [CrossRef] [PubMed]

25. Bergsagel, P.L.; Kuehl, W.M. Chromosome translocations in multiple myeloma. Oncogene 2001, 20, 5611-5622. [PubMed]

26. Kumar, S.; Fonseca, R.; Ketterling, R.P.; Dispenzieri, A.; Lacy, M.Q.; Gertz, M.A.; Hayman, S.R.; Buadi, F.K.; Dingli, D.; Knudson, R.A.; et al. Trisomies in multiple myeloma: Impact on survival in patients with high-risk cytogenetics. Blood 2012, 119, 2100-2105. [CrossRef] [PubMed]

27. Dimopoulos, K.; Gimsing, P.; Grønbæk, K. The role of epigenetics in the biology of multiple myeloma. Blood Cancer J. 2014, 4, e207.

28. López-Corral, L.; Gutiérrez, N.C.; Vidriales, M.B.; Mateos, M.V.; Rasillo, A.; García-Sanz, R.; Paiva, B.; San Miguel, J.F. The progression from MGUS to smoldering myeloma and eventually to multiple myeloma involves a clonal expansion of genetically abnormal plasma cells. Clin. Cancer Res. 2011, 17, 1692-1700. [CrossRef]

29. Keats, J.J.; Chesi, M.; Egan, J.B.; Garbitt, V.M.; Palmer, S.E.; Braggio, E.; Van Wier, S.; Blackburn, P.R.; Baker, A.S.; Dispenzieri, A.; et al. Clonal competition with alternating dominance in multiple myeloma. Blood 2012, 120, 1067-1076. 
30. Walker, B.A.; Wardell, C.P.; Melchor, L.; Brioli, A.; Johnson, D.C.; Kaiser, M.F.; Mirabella, F.; Lopez-Corral, L.; Humphray, S.; Murray, L.; et al. Intraclonal heterogeneity is a critical early event in the development of myeloma and precedes the development of clinical symptoms. Leukemia 2014, 28, 384-390. [CrossRef]

31. Lohr, J.G.; Stojanov, P.; Carter, S.L.; Cruz-Gordillo, P.; Lawrence, M.S.; Auclair, D.; Sougnez, C.; Knoechel, B.; Gould, J.; Saksena, G.; et al. Widespread Genetic Heterogeneity in Multiple Myeloma: Implications for Targeted Therapy. Cancer Cell 2014, 25, 91-101. [CrossRef]

32. Ohguchi, H.; Hideshima, T.; Anderson, K.C. The modifiers in multiple myeloma: Clinical applications. Blood Cancer J. 2018, 8, 1-13. [CrossRef] [PubMed]

33. Amodio, N.; D'Aquila, P.; Passarino, G.; Tassone, P.; Bellizzi, D. Epigenetic modifications in multiple myeloma: Recent advances on the role of DNA and histone methylation. Expert Opin. Ther. Targets 2017, 21, 91-101. [CrossRef] [PubMed]

34. Sive, J.I.; Feber, A.; Smith, D.; Quinn, J.; Beck, S.; Yong, K. Global hypomethylation in myeloma is associated with poor prognosis. Br. J. Haematol. 2016, 172, 473-475. [PubMed]

35. Agirre, X.; Castellano, G.; Pascual, M.; Heath, S.; Kulis, M.; Segura, V.; Bergmann, A.; Esteve, A.; Merkel, A.; Raineri, E. Whole-epigenome analysis in multiple myeloma reveals DNA hypermethylation of B cell-specific enhancers. Genome Res. 2015, 25, 478-487. [CrossRef] [PubMed]

36. Walker, B.A.; Wardell, C.P.; Chiecchio, L.; Smith, E.M.; Boyd, K.D.; Neri, A.; Davies, F.E.; Ross, F.M.; Morgan, G.J. Aberrant global methylation patterns affect the molecular pathogenesis and prognosis of multiple myeloma. Blood 2011, 117, 553-562. [CrossRef]

37. Chim, C.S.; Liang, R.; Leung, M.H.; Yip, S.F.; Kwong, Y.L. Aberrant gene promoter methylation marking disease progression in multiple myeloma. Leukemia 2006, 20, 1190-1192. [CrossRef] [PubMed]

38. Chapman, M.A.; Lawrence, M.S.; Keats, J.J.; Cibulskis, K.; Sougnez, C.; Schinzel, A.C.; Harview, C.L.; Brunet, J.-P.; Ahmann, G.J.; Adli, M.; et al. Initial genome sequencing and analysis of multiple myeloma. Nature 2011, 471, 467-472. [CrossRef] [PubMed]

39. Pawlyn, C.; Kaiser, M.F.; Heuck, C.; Melchor, L.; Wardell, C.P.; Murison, A.; Chavan, S.S.; Johnson, D.C.; Begum, D.B.; Dahir, N.M.; et al. The Spectrum and Clinical Impact of Epigenetic Modifier Mutations in Myeloma. Clin. Cancer Res. 2016, 22, 5783-5794. [CrossRef]

40. Wong, K.Y.; Huang, X.; Chim, C.S. DNA methylation of microRNA genes in multiple myeloma. Carcinogenesis 2012, 33, 1629-1638.

41. Zhang, W.; Wang, Y.E.; Zhang, Y.; Leleu, X.; Reagan, M.; Zhang, Y.; Mishima, Y.; Glavey, S.; Manier, S.; Sacco, A.; et al. Global epigenetic regulation of microRNAs in multiple myeloma. PLoS ONE 2014, 9, e110973.

42. Wong, K.Y.; So, C.C.; Loong, F.; Chung, L.P.; Lam, W.W.L.; Liang, R.; Li, G.K.H.; Jin, D.-Y.; Chim, C.S. Epigenetic inactivation of the miR-124-1 in haematological malignancies. PLOS ONE 2011, 6, e19027. [CrossRef] [PubMed]

43. Lujambio, A.; Ropero, S.; Ballestar, E.; Fraga, M.F.; Cerrato, C.; Setién, F.; Casado, S.; Suarez-Gauthier, A.; Sanchez-Cespedes, M.; Gitt, A.; et al. Genetic Unmasking of an Epigenetically Silenced microRNA in Human Cancer Cells. Cancer Res. 2007, 67, 1424-1429. [CrossRef] [PubMed]

44. Melo, S.A.; Esteller, M. Dysregulation of microRNAs in cancer: Playing with fire. FEBS Lett. 2011, 585, 2087-2099. [PubMed]

45. Sato, F.; Tsuchiya, S.; Meltzer, S.J.; Shimizu, K. MicroRNAs and epigenetics. FEBS Lett 2011, 278, $1598-1609$. [CrossRef] [PubMed]

46. Kozaki, K.-I.; Inazawa, J. Tumor-suppressive microRNA silenced by tumor-specific DNA hypermethylation in cancer cells. Cancer Sci. 2012, 103, 837-845. [CrossRef] [PubMed]

47. Fabbri, M.; Garzon, R.; Cimmino, A.; Liu, Z.; Zanesi, N.; Callegari, E.; Liu, S.; Alder, H.; Costinean, S.; Fernandez-Cymering, C.; et al. MicroRNA-29 family reverts aberrant methylation in lung cancer by targeting DNA methyltransferases 3A and 3B. Proc. Natl. Acad. Sci. USA 2007, 104, 15805-15810. [CrossRef]

48. Amodio, N.; Bellizzi, D.; Leotta, M.; Raimondi, L.; Biamonte, L.; D’Aquila, P.; Di Martino, M.T.; Calimeri, T.; Rossi, M.; Lionetti, M. Mir-29b induces socs-1 expression by promoter demethylation and negatively regulates migration of multiple myeloma and endothelial cells. Cell Cycle 2013, 12, 3650-3662. [CrossRef]

49. Chaidos, A.; Barnes, C.P.; Cowan, G.; May, P.C.; Melo, V.; Hatjiharissi, E.; Papaioannou, M.; Harrington, H.; Doolittle, H.; Terpos, E.; et al. Clinical drug resistance linked to interconvertible phenotypic and functional states of tumor-propagating cells in multiple myeloma. Blood 2013, 121, 318-328. [CrossRef] 
50. Paiva, B.; Puig, N.; Cedena, M.T.; de Jong, B.G.; Ruiz, Y.; Rapado, I.; Martinez-Lopez, J.; Cordon, L.; Alignani, D.; Delgado, J.A.; et al. Differentiation stage of myeloma plasma cells: Biological and clinical significance. Leukemia 2017, 31, 382-392. [CrossRef]

51. Williams, K.; Christensen, J.; Helin, K. DNA methylation: TET proteins-Guardians of CpG islands? EMBO Rep. 2012, 13, 28-35. [CrossRef] [PubMed]

52. Chim, C.-S.; Liang, R.; Leung, M.-H.; Kwong, Y.-L. Aberrant gene methylation implicated in the progression of monoclonal gammopathy of undetermined significance to multiple myeloma. J. Clin. Pathol. 2007, 60, 104-106. [CrossRef] [PubMed]

53. Reddy, J.; Shivapurkar, N.; Takahashi, T.; Parikh, G.; Stastny, V.; Echebiri, C.; Crumrine, K.; Zöchbauer-Müller, S.; Drach, J.; Zheng, Y.; et al. Differential methylation of genes that regulate cytokine signaling in lymphoid and hematopoietic tumors. Oncogene 2005, 24, 732-736. [PubMed]

54. Robertson, K.D. DNA methylation and human disease. Nat. Rev. Genet. 2005, 6, 597-610. [CrossRef]

55. Liang, G.; Weisenberger, D.J. DNA methylation aberrancies as a guide for surveillance and treatment of human cancers. Epigenetics 2017, 12, 416-432. [CrossRef]

56. Ng, M.H.; To, K.; Lo, K.; Chan, S.; Tsang, K.; Cheng, S.; Ng, H. Frequent death-associated protein kinase promoter hypermethylation in multiple myeloma. Clin. Cancer Res. 2001, 7, 1724-1729.

57. Chim, C.-S.; Fung, T.-K.; Cheung, W.-C.; Liang, R.; Kwong, Y.-L. SOCS1 and SHP1 hypermethylation in multiple myeloma: Implications for epigenetic activation of the Jak/STAT pathway. Blood 2004, 103, 4630-4635. [CrossRef]

58. Houde, C.; Li, Y.; Song, L.; Barton, K.; Zhang, Q.; Godwin, J.; Nand, S.; Toor, A.; Alkan, S.; Smadja, N.V.; et al. Overexpression of the NOTCH ligand JAG2 in malignant plasma cells from multiple myeloma patients and cell lines. Blood 2004, 104, 3697-3704. [CrossRef]

59. Hoffman, R.M. Is DNA methylation the new guardian of the genome? Mol. Cytogenet. 2017, 10, 11. [CrossRef]

60. Bollati, V.; Fabris, S.; Pegoraro, V.; Ronchetti, D.; Mosca, L.; Deliliers, G.L.; Motta, V.; Bertazzi, P.A.; Baccarelli, A.; Neri, A. Differential repetitive DNA methylation in multiple myeloma molecular subgroups. Carcinogenesis 2009, 30, 1330-1335. [CrossRef]

61. Turner, J.G.; Gump, J.L.; Zhang, C.; Cook, J.M.; Marchion, D.; Hazlehurst, L.; Munster, P.; Schell, M.J.; Dalton, W.S.; Sullivan, D.M. ABCG2 expression, function, and promoter methylation in human multiple myeloma. Blood 2006, 108, 3881-3889. [PubMed]

62. Chim, C.S.; Wong, K.Y.; Qi, Y.; Loong, F.; Lam, W.L.; Wong, L.G.; Jin, D.Y.; Costello, J.F.; Liang, R. Epigenetic inactivation of the miR-34a in hematological malignancies. Carcinogenesis 2010, 31, 745-750. [CrossRef] [PubMed]

63. Wong, K.-Y.; Liang, R.; So, C.-C.; Jin, D.-Y.; Costello, J.F.; Chim, C.-S. Epigenetic silencing of MIR203 in multiple myeloma. Br. J. Haematol. 2011, 154, 569-578. [CrossRef]

64. Wong, K.Y.; Yim, R.L.H.; So, C.C.; Jin, D.-Y.; Liang, R.; Chim, C.S. Epigenetic inactivation of the MIR34B/C in multiple myeloma. Blood 2011, 118, 5901-5904. [PubMed]

65. Wong, K.-Y.; Yim, R.L.-H.; Kwong, Y.-L.; Leung, C.-Y.; Hui, P.-K.; Cheung, F.; Liang, R.; Jin, D.-Y.; Chim, C.-S. Epigenetic inactivation of the MIR129-2 in hematological malignancies. J. Hematol. Oncol. 2013, 6, 16. [CrossRef]

66. Wong, K.Y.; Chim, C.S. DNA methylation of tumor suppressor protein-coding and non-coding genes in multiple myeloma. Epigenomics 2015, 7, 985-1001. [CrossRef]

67. Kouzarides, T. Chromatin Modifications and Their Function. Cell 2007, 128, 693-705. [CrossRef]

68. Lennartsson, A.; Ekwall, K. Histone modification patterns and epigenetic codes. Biochim. Biophys. Acta (BBA)-Gen. Subj. 2009, 1790, 863-868. [CrossRef]

69. Füllgrabe, J.; Kavanagh, E.; Joseph, B. Histone onco-modifications. Oncogene 2011, 30, 3391-3403. [CrossRef]

70. Li, B.; Carey, M.; Workman, J.L. The Role of Chromatin during Transcription. Cell 2007, 128, 707-719. [CrossRef]

71. Dupéré-Richer, D.; Licht, J.D. Epigenetic regulatory mutations and epigenetic therapy for multiple myeloma. Curr. Opin. Hematol. 2017, 24, 336-344. [CrossRef] [PubMed]

72. Min, D.J.; Ezponda, T.; Kim, M.K.; Will, C.M.; Martinez-Garcia, E.; Popovic, R.; Basrur, V.; Elenitoba-Johnson, K.S.; Licht, J.D. MMSET stimulates myeloma cell growth through microRNA-mediated modulation of c-MYC. Leukemia 2013, 27, 686-694. [CrossRef] [PubMed] 
73. Kariyawasan, C.C.; Hughes, D.A.; Jayatillake, M.M.; Mehta, A.B. Multiple myeloma: Causes and consequences of delay in diagnosis. QJM 2007, 100, 635-640. [CrossRef] [PubMed]

74. Katzmann, J.A.; Dispenzieri, A.; Kyle, R.A.; Snyder, M.R.; Plevak, M.F.; Larson, D.R.; Abraham, R.S.; Lust, J.A.; Melton III, L.J.; Rajkumar, S.V. Elimination of the need for urine studies in the screening algorithm for monoclonal gammopathies by using serum immunofixation and free light chain assays. Mayo Clin. Proc. 2006, 81, 1575-1578. [CrossRef]

75. Chawla, S.S.; Kumar, S.K.; Dispenzieri, A.; Greenberg, A.J.; Larson, D.R.; Kyle, R.A.; Lacy, M.Q.; Gertz, M.A.; Rajkumar, S.V. Clinical course and prognosis of non-secretory multiple myeloma. Eur. J. Haematol. 2015, 95, 57-64. [CrossRef]

76. Hillengass, J.; Fechtner, K.; Weber, M.; Bauerle, T.; Ayyaz, S.; Heiss, C.; Hielscher, T.; Moehler, T.M.; Egerer, G.; Neben, K.; et al. Prognostic significance of focal lesions in whole-body magnetic resonance imaging in patients with asymptomatic multiple myeloma. J. Clin. Oncol. 2010, 28, 1606-1610. [CrossRef]

77. Rajkumar, S.V.; Kumar, S. Multiple myeloma: Diagnosis and treatment. Mayo Clin. Proc. 2016, 91, 101-119. [CrossRef]

78. Bartel, D.P. MicroRNAs: Genomics, biogenesis, mechanism, and function. Cell 2004, 116, 281-297. [CrossRef]

79. Soliman, A.M.; Das, S.; Abd Ghafar, N.; Teoh, S.L. Role of microRNA in proliferation phase of wound healing. Front. Genet. 2018, 9, 38.

80. Lee, Y.; Jeon, K.; Lee, J.; Kim, S.; Kim, V.N. MicroRNA maturation: Stepwise processing and subcellular localization. EMBO J. 2002, 21, 4663-4670.

81. Bartel, D.P. MicroRNAs: Target recognition and regulatory functions. Cell 2009, 136, 215-233. [CrossRef] [PubMed]

82. Anastasiadou, E.; Jacob, L.S.; Slack, F.J. Non-coding RNA networks in cancer. Nat. Rev. Cancer 2018, 18, 5-18. [PubMed]

83. Peng, Y.; Croce, C.M. The role of MicroRNAs in human cancer. Signal. Transduct Target. 2016, 1, 15004.

84. Teoh, S.L.; Das, S. The role of microRNAs in diagnosis, prognosis, metastasis and resistant cases in breast cancer. Curr. Pharm. Des. 2017, 23, 1845-1859. [CrossRef]

85. Svoronos, A.A.; Engelman, D.M.; Slack, F.J. OncomiR or tumor suppressor? The duplicity of microRNAs in cancer. Cancer Res. 2016, 76, 3666-3670. [CrossRef]

86. Hayes, J.; Peruzzi, P.P.; Lawler, S. MicroRNAs in cancer: Biomarkers, functions and therapy. Trends Mol. Med. 2014, 20, 460-469. [CrossRef]

87. Xu, L.; Yang, B.-f.; Ai, J. MicroRNA transport: A new way in cell communication. J. Cell Physiol. 2013, 228, 1713-1719. [CrossRef]

88. Wang, K.; Zhang, S.; Weber, J.; Baxter, D.; Galas, D.J. Export of microRNAs and microRNA-protective protein by mammalian cells. Nucleic Acids Res. 2010, 38, 7248-7259.

89. Gong, J.; Jaiswal, R.; Mathys, J.M.; Combes, V.; Grau, G.E.R.; Bebawy, M. Microparticles and their emerging role in cancer multidrug resistance. Cancer Treat. Rev. 2012, 38, 226-234. [CrossRef]

90. Cui, M.; Wang, H.; Yao, X.; Zhang, D.; Xie, Y.; Cui, R.; Zhang, X. Circulating MicroRNAs in Cancer: Potential and Challenge. Front. Genet. 2019, 10, 626. [CrossRef]

91. Heijnen, H.F.; Schiel, A.E.; Fijnheer, R.; Geuze, H.J.; Sixma, J.J. Activated Platelets Release Two Types of Membrane Vesicles: Microvesicles by Surface Shedding and Exosomes Derived from Exocytosis of Multivesicular Bodies and Granules. Blood 1999, 94, 3791-3799. [CrossRef] [PubMed]

92. Hunter, M.P.; Ismail, N.; Zhang, X.; Aguda, B.D.; Lee, E.J.; Yu, L.; Xiao, T.; Schafer, J.; Lee, M.-L.T.; Schmittgen, T.D.; et al. Detection of microRNA expression in human peripheral blood microvesicles. PLOS ONE 2008, 3, e3694.

93. Chang, J.; Nicolas, E.; Marks, D.; Sander, C.; Lerro, A.; Buendia, M.A.; Xu, C.; Mason, W.S.; Moloshok, T.; Bort, R.; et al. miR-122, a Mammalian Liver-Specific microRNA, is Processed from hor mRNA and MayDownregulate the High Affinity Cationic Amino Acid Transporter CAT-1. RNA Biol. 2004, 1, 106-113. [CrossRef] [PubMed]

94. Yao, B.; La, L.B.; Chen, Y.-C.; Chang, L.-J.; Chan, E.K.L. Defining a new role of GW182 in maintaining miRNA stability. EMBO Rep. 2012, 13, 1102-1108. [CrossRef] [PubMed]

95. Montani, F.; Bianchi, F. Circulating Cancer Biomarkers: The Macro-revolution of the Micro-RNA. EBioMedicine 2016, 5, 4-6. [CrossRef] [PubMed] 
96. Smith, S.M.; Murray, D.W. An overview of microRNA methods: Expression profiling and target identification. In Molecular Profiling; Espina, V., Liotta, L., Eds.; Humana Press: New York, NY, USA, 2012; pp. 119-138.

97. Hu, Y.; Lan, W.; Miller, D. Next-generation sequencing for microRNA expression profile. In Bioinformatics in microRNA Research; Huang, J., Borchert, G.M., Dou, D., Huan, J., Lan, W., Tan, M., Wu, B., Eds.; Humana Press: New York, NY, USA, 2017; pp. 169-177.

98. Pichiorri, F.; Suh, S.; Ladetto, M.; Kuehl, M.; Palumbo, T.; Drandi, D.; Taccioli, C.; Zanesi, N.; Alder, H.; Hagan, J.P.; et al. MicroRNAs regulate critical genes associated with multiple myeloma pathogenesis. Proc. Natl. Acad. Sci. USA 2008, 105, 12885-12890. [CrossRef] [PubMed]

99. Li, B.; Xu, H.; Han, H.; Song, S.; Zhang, X.; Ouyang, L.; Qian, C.a.; Hong, Y.; Qiu, Y.; Zhou, W.; et al. Exosome-mediated transfer of lncRUNX2-AS1 from multiple myeloma cells to MSCs contributes to osteogenesis. Oncogene 2018, 37, 5508-5519. [CrossRef]

100. Gulei, D.; Petrut, B.; Tigu, A.B.; Onaciu, A.; Fischer-Fodor, E.; Atanasov, A.G.; Ionescu, C.; Berindan-Neagoe, I. Exosomes at a glance-Common nominators for cancer hallmarks and novel diagnosis tools. Crit. Rev. Biochem. Mol. Biol. 2018, 53, 564-577. [CrossRef]

101. Boyiadzis, M.; Whiteside, T.L. The emerging roles of tumor-derived exosomes in hematological malignancies. Leukemia 2017, 31, 1259-1268. [CrossRef]

102. Abdi, J.; Qiu, L.; Chang, H. Micro-RNAs, New performers in multiple myeloma bone marrow microenvironment. Biomark. Res. 2014, 2, 10. [CrossRef]

103. Di Marzo, L.; Desantis, V.; Solimando, A.G.; Ruggieri, S.; Annese, T.; Nico, B.; Fumarulo, R.; Vacca, A.; Frassanito, M.A. Microenvironment drug resistance in multiple myeloma: Emerging new players. Oncotarget 2016, 7, 60698. [CrossRef] [PubMed]

104. Zhang, Y.-K.; Wang, H.; Leng, Y.; Li, Z.-L.; Yang, Y.-F.; Xiao, F.-J.; Li, Q.-F.; Chen, X.-Q.; Wang, L.-S. Overexpression of microrna-29b induces apoptosis of multiple myeloma cells through down regulating mcl-1. Biochem. Biophys. Res. Commun. 2011, 414, 233-239. [CrossRef] [PubMed]

105. Jiang, Y.; Chang, H.; Chen, G. Effects of microRNA-20a on the proliferation, migration and apoptosis of multiple myeloma via the PTEN/PI3K/AKT signaling pathway. Oncol. Lett. 2018, 15, 10001-10007. [CrossRef] [PubMed]

106. Yang, N.; Chen, J.; Zhang, H.; Wang, X.; Yao, H.; Peng, Y.; Zhang, W. LncRNA OIP5-AS1 loss-induced microRNA-410 accumulation regulates cell proliferation and apoptosis by targeting KLF10 via activating PTEN/PI3K/AKT pathway in multiple myeloma. Cell Death Dis. 2017, 8, e2975. [CrossRef]

107. Yu, T.; Zhang, X.; Zhang, L.; Wang, Y.; Pan, H.; Xu, Z.; Pang, X. Microrna-497 suppresses cell proliferation and induces apoptosis through targeting pbx3 in human multiple myeloma. Am. J. Cancer Res. 2016, 6, 2880.

108. Xu, Z.; Huang, C.; Hao, D. MicroRNA-1271 inhibits proliferation and promotes apoptosis of multiple myeloma cells through inhibiting smoothened-mediated Hedgehog signaling pathway. Oncol. Rep. 2017, 37, 1261-1269. [CrossRef]

109. Shain, K.H.; Yarde, D.N.; Meads, M.B.; Huang, M.; Jove, R.; Hazlehurst, L.A.; Dalton, W.S. Beta1 integrin adhesion enhances IL-6-mediated STAT3 signaling in myeloma cells: Implications for microenvironment influence on tumor survival and proliferation. Cancer Res. 2009, 69, 1009-1015. [CrossRef]

110. Gupta, D.; Treon, S.P.; Shima, Y.; Hideshima, T.; Podar, K.; Tai, Y.T.; Lin, B.; Lentzsch, S.; Davies, F.E.; Chauhan, D.; et al. Adherence of multiple myeloma cells to bone marrow stromal cells upregulates vascular endothelial growth factor secretion: Therapeutic applications. Leukemia 2001, 15, 1950-1961. [CrossRef]

111. Hideshima, T.; Mitsiades, C.; Tonon, G.; Richardson, P.G.; Anderson, K.C. Understanding multiple myeloma pathogenesis in the bone marrow to identify new therapeutic targets. Nat. Rev. Cancer 2007, 7, 585-598.

112. Roccaro, A.M.; Sacco, A.; Maiso, P.; Azab, A.K.; Tai, Y.-T.; Reagan, M.; Azab, F.; Flores, L.M.; Campigotto, F.; Weller, E.; et al. BM mesenchymal stromal cell-derived exosomes facilitate multiple myeloma progression. J. Clin. Investig. 2013, 123, 1542-1555. [CrossRef]

113. Ell, B.; Kang, Y. MicroRNAs as regulators of tumor-associated stromal cells. Oncotarget 2013, 4, $2166-2167$. [CrossRef] [PubMed]

114. Zhang, Y.; Yang, P.; Wang, X.-F. Microenvironmental regulation of cancer metastasis by miRNAs. Trends Cell Biol. 2014, 24, 153-160. [CrossRef] [PubMed]

115. Umezu, T.; Tadokoro, H.; Azuma, K.; Yoshizawa, S.; Ohyashiki, K.; Ohyashiki, J.H. Exosomal mir-135b shed from hypoxic multiple myeloma cells enhances angiogenesis by targeting factor-inhibiting hif- 1 . Blood 2014, 124, 3748-3757. [CrossRef] [PubMed] 
116. Raimondi, L.; Amodio, N.; Di Martino, M.T.; Altomare, E.; Leotta, M.; Caracciolo, D.; Gullà, A.; Neri, A.; Taverna, S.; D'Aquila, P.; et al. Targeting of multiple myeloma-related angiogenesis by miR-199a-5p mimics: In vitro and in vivo anti-tumor activity. Oncotarget 2014, 5, 3039-3054. [CrossRef] [PubMed]

117. Ria, R.; Reale, A.; De Luisi, A.; Ferrucci, A.; Moschetta, M.; Vacca, A. Bone marrow angiogenesis and progression in multiple myeloma. Am. J. Blood Res. 2011, 1, 76-89.

118. Umezu, T.; Imanishi, S.; Yoshizawa, S.; Kawana, C.; Ohyashiki, J.H.; Ohyashiki, K. Induction of multiple myeloma bone marrow stromal cell apoptosis by inhibiting extracellular vesicle miR-10a secretion. Blood Adv. 2019, 3, 3228-3240. [CrossRef]

119. Liu, N.; Yang, J.; Yuan, R.; Peng, J.; Liu, L.; Guo, X. Effects of miR-181a on the biological function of multiple myeloma. Oncol. Rep. 2019, 42, 291-300. [CrossRef]

120. Frassanito, M.A.; Desantis, V.; Di Marzo, L.; Craparotta, I.; Beltrame, L.; Marchini, S.; Annese, T.; Visino, F.; Arciuli, M.; Saltarella, I.; et al. Bone marrow fibroblasts overexpress miR-27b and miR-214 in step with multiple myeloma progression, dependent on tumour cell-derived exosomes. J. Pathol. 2019, 247, 241-253. [CrossRef]

121. Rossi, M.; Altomare, E.; Botta, C.; Gallo Cantafio, M.E.; Sarvide, S.; Caracciolo, D.; Riillo, C.; Gaspari, M.; Taverna, D.; Conforti, F.; et al. miR-21 antagonism abrogates Th17 tumor promoting functions in multiple myeloma. Leukemia 2020. [CrossRef]

122. Di Martino, M.T.; Rossi, M.; Caracciolo, D.; Gullà, A.; Tagliaferri, P.; Tassone, P. Mir-221/222 are promising targets for innovative anticancer therapy. Expert Opin. Ther. Targets 2016, 20, 1099-1108. [CrossRef]

123. Di Martino, M.T.; Gullà, A.; Cantafio, M.E.G.; Lionetti, M.; Leone, E.; Amodio, N.; Guzzi, P.H.; Foresta, U.; Conforti, F.; Cannataro, M. In vitro and in vivo anti-tumor activity of miR-221/222 inhibitors in multiple myeloma. Oncotarget 2013, 4, 242-255. [CrossRef]

124. Leone, E.; Morelli, E.; Di Martino, M.T.; Amodio, N.; Foresta, U.; Gullà, A.; Rossi, M.; Neri, A.; Giordano, A.; Munshi, N.C.; et al. Targeting miR-21 inhibits in vitro and in vivo multiple myeloma cell growth. Clin. Cancer Res. 2013, 19, 2096-2106. [CrossRef]

125. Lionetti, M.; Agnelli, L.; Mosca, L.; Fabris, S.; Andronache, A.; Todoerti, K.; Ronchetti, D.; Deliliers, G.L.; Neri, A. Integrative high-resolution microarray analysis of human myeloma cell lines reveals deregulated miRNA expression associated with allelic imbalances and gene expression profiles. Genes Chromosomes Cancer 2009, 48, 521-531. [CrossRef]

126. Leotta, M.; Biamonte, L.; Raimondi, L.; Ronchetti, D.; Di Martino, M.T.; Botta, C.; Leone, E.; Pitari, M.R.; Neri, A.; Giordano, A.; et al. A p53-dependent tumor suppressor network is induced by selective miR-125a-5p inhibition in multiple myeloma cells. J. Cell Physiol. 2014, 229, 2106-2116. [CrossRef]

127. Yuan, J.; Su, Z.; Gu, W.; Shen, X.; Zhao, Q.; Shi, L.; Jin, C.; Wang, X.; Cong, H.; Ju, S. MiR-19b and miR-20a suppress apoptosis, promote proliferation and induce tumorigenicity of multiple myeloma cells by targeting PTEN. Cancer Biomark. 2019, 24, 279-289. [CrossRef]

128. Che, F.; Wan, C.; Dai, J.; Chen, J. Increased expression of miR-27 predicts poor prognosis and promotes tumorigenesis in human multiple myeloma. Biosci. Rep. 2019, 39, BSR20182502. [CrossRef]

129. Gu, C.; Li, T.; Yin, Z.; Chen, S.; Fei, J.; Shen, J.; Zhang, Y. Integrative analysis of signaling pathways and diseases associated with the miR-106b/25 cluster and their function study in berberine-induced multiple myeloma cells. Funct. Integr. Genom. 2017, 17, 253-262. [CrossRef]

130. Xu, J.; Su, Y.; Xu, A.; Fan, F.; Mu, S.; Chen, L.; Chu, Z.; Zhang, B.; Huang, H.; Zhang, J.; et al. miR-221/222-mediated inhibition of autophagy promotes dexamethasone resistance in multiple myeloma. Molecules 2019, 27, 559-570. [CrossRef]

131. Hu, Y.; Liu, H.; Fang, C.; Li, C.; Xhyliu, F.; Dysert, H.; Bodo, J.; Habermehl, G.; Russell, B.E.; Li, W.; et al. Targeting of CD38 by the tumor suppressor miR-26a serves as a novel potential therapeutic agent in multiple myeloma. Cancer Res. 2020, 80, 2031-2044. [CrossRef]

132. Wang, H.; Ding, Q.; Wang, M.; Guo, M.; Zhao, Q. miR-29b inhibits the progression of multiple myeloma through downregulating FOXP1. Hematology 2019, 24, 32-38. [CrossRef]

133. Wu, H.; Wang, X.; Wu, T.; Yang, S. miR-489 suppresses multiple myeloma cells growth through inhibition of LDHA-mediated aerobic glycolysis. Genes Genom 2020, 42, 291-297. [CrossRef]

134. Amodio, N.; Gallo Cantafio, M.E.; Botta, C.; Agosti, V.; Federico, C.; Caracciolo, D.; Ronchetti, D.; Rossi, M.; Driessen, C.; Neri, A.; et al. Replacement of miR-155 elicits tumor suppressive activity and antagonizes bortezomib resistance in multiple myeloma. Cancers 2019, 11, 236. [CrossRef] [PubMed] 
135. Xiao, X.; Gu, Y.; Wang, G.; Chen, S. c-Myc, RMRP, and miR-34a-5p form a positive-feedback loop to regulate cell proliferation and apoptosis in multiple myeloma. Int. J. Biol. Macromol. 2019, 122, 526-537. [CrossRef]

136. Roccaro, A.M.; Sacco, A.; Thompson, B.J.; Leleu, X.; Azab, A.K.; Azab, F.; Runnels, J.; Jia, X.; Ngo, H.T.; Melhem, M.R.; et al. MicroRNAs 15a and 16 regulate tumor proliferation in multiple myeloma. Blood 2009, 113, 6669-6680.

137. Morelli, E.; Leone, E.; Gallo Cantafio, M.E.; Di Martino, M.T.; Amodio, N.; Biamonte, L.; Gullà, A.; Foresta, U.; Pitari, M.R.; Botta, C.; et al. Selective targeting of IRF4 by synthetic microRNA-125b-5p mimics induces anti-multiple myeloma activity in vitro and in vivo. Leukemia 2015, 29, 2173-2183. [CrossRef]

138. Tassone, P.; Galea, E.; Forciniti, S.; Tagliaferri, P.; Venuta, S. The IL-6 receptor super-antagonist Sant7 enhances antiproliferative and apoptotic effects induced by dexamethasone and zoledronic acid on multiple myeloma cells. Int. J. Oncol. 2002, 21, 867-873. [CrossRef]

139. Hamasaki, M.; Hideshima, T.; Tassone, P.; Neri, P.; Ishitsuka, K.; Yasui, H.; Shiraishi, N.; Raje, N.; Kumar, S.; Picker, D.H. Azaspirane (NN-diethyl-8, 8-dipropyl-2-azaspiro [4.5] decane-2-propanamine) inhibits human multiple myeloma cell growth in the bone marrow milieu in vitro and in vivo. Blood 2005, 105, 4470-4476. [CrossRef]

140. Misso, G.; Zarone, M.R.; Lombardi, A.; Grimaldi, A.; Cossu, A.M.; Ferri, C.; Russo, M.; Vuoso, D.C.; Luce, A.; Kawasaki, H.; et al. miR-125b upregulates miR-34a and sequentially activates stress adaption and cell death mechanisms in multiple myeloma. Mol. Nucleic Acids 2019, 16, 391-406. [CrossRef]

141. Tian, Z.; Zhao, J.; Tai, Y.; Amin, S.B.; Hu, Y.; Berger, A.J.; Richardson, P.; Chauhan, D.; Anderson, K.C. Investigational agent MLN9708/2238 targets tumor-suppressor miR33b in MM cells. Blood 2012, 120, 3958-3967. [CrossRef]

142. Selivanova, G. Wild type p53 reactivation: From lab bench to clinic. FEBS Lett. 2014, 588, 2628-2638. [CrossRef]

143. Di Martino, M.T.; Leone, E.; Amodio, N.; Foresta, U.; Lionetti, M.; Pitari, M.R.; Cantafio, M.E.G.; Gullà, A.; Conforti, F.; Morelli, E. Synthetic miR-34a mimics as a novel therapeutic agent for multiple myeloma: In vitro and in vivo evidence. Clin. Cancer Res. 2012, 18, 6260-6270. [CrossRef]

144. Wu, S.; He, X.; Li, M.; Shi, F.; Wu, D.; Pan, M.; Guo, M.; Zhang, R.; Luo, S.; Gu, N. MiRNA-34a overexpression inhibits multiple myeloma cancer stem cell growth in mice by suppressing TGIF2. Am. J. Transl. Res. 2016, 8, 5433-5443.

145. Amodio, N.; Di Martino, M.T.; Foresta, U.; Leone, E.; Lionetti, M.; Leotta, M.; Gulla, A.M.; Pitari, M.R.; Conforti, F.; Rossi, M. miR-29b sensitizes multiple myeloma cells to bortezomib-induced apoptosis through the activation of a feedback loop with the transcription factor Sp1. Cell Death Dis. 2012, 3, e436. [CrossRef]

146. Neri, P.; Tagliaferri, P.; Di Martino, M.T.; Calimeri, T.; Amodio, N.; Bulotta, A.; Ventura, M.; Eramo, P.O.; Viscomi, C.; Arbitrio, M.; et al. In vivo anti-myeloma activity and modulation of gene expression profile induced by valproic acid, a histone deacetylase inhibitor. Br. J. Haematol. 2008, 143, 520-531.

147. Amodio, N.; Leotta, M.; Bellizzi, D.; Di Martino, M.T.; D'Aquila, P.; Lionetti, M.; Fabiani, F.; Leone, E.; Gullà, A.M.; Passarino, G. DNA-demethylating and anti-tumor activity of synthetic miR-29b mimics in multiple myeloma. Oncotarget 2012, 3, 1246-1258. [CrossRef]

148. Amodio, N.; Stamato, M.A.; Gullà, A.M.; Morelli, E.; Romeo, E.; Raimondi, L.; Pitari, M.R.; Ferrandino, I.; Misso, G.; Caraglia, M. Therapeutic targeting of miR-29b/HDAC4 epigenetic loop in multiple myeloma. Mol. Cancer 2016, 15, 1364-1375. [CrossRef]

149. Jagannathan, S.; Vad, N.; Vallabhapurapu, S.; Anderson, K.C.; Driscoll, J.J. MiR-29b replacement inhibits proteasomes and disrupts aggresome+autophagosome formation to enhance the antimyeloma benefit of bortezomib. Leukemia 2015, 29, 727-738.

150. Pichiorri, F.; Suh, S.; Rocci, A.; De Luca, L.; Taccioli, C.; Santhanam, R.; Zhou, W.; Benson Jr, D.M.; Hofmainster, C.; Alder, H.; et al. Downregulation of p53-inducible microRNAs 192, 194, and 215 impairs the p53/MDM2 autoregulatory loop in multiple myeloma development. Cancer Cell 2010, 18, 367-381. [CrossRef]

151. Misiewicz-Krzeminska, I.; Sarasquete, M.E.; Quwaider, D.; Krzeminski, P.; Ticona, F.V.; Paíno, T.; Delgado, M.; Aires, A.; Ocio, E.M.; García-Sanz, R.; et al. Restoration of microRNA-214 expression reduces growth of myeloma cells through positive regulation of P53 and inhibition of DNA replication. Haematologica 2013, 98, 640-648. [CrossRef]

152. Yuan, X.; Ma, R.; Yang, S.; Jiang, L.; Wang, Z.; Zhu, Z.; Li, H. miR-520g and miR-520h overcome bortezomib resistance in multiple myeloma via suppressing APE1. Cell Cycle 2019, 18, 1660-1669. [CrossRef] 
153. Caracciolo, D.; Di Martino, M.T.; Amodio, N.; Morelli, E.; Montesano, M.; Botta, C.; Scionti, F.; Talarico, D.; Altomare, E.; Gallo Cantafio, M.E.; et al. miR-22 suppresses DNA ligase III addiction in multiple myeloma. Leukemia 2019, 33, 487-498. [PubMed]

154. Wu, L.; Zhang, C.; Chu, M.; Fan, Y.; Wei, L.; Li, Z.; Yao, Y.; Zhuang, W. miR-125a suppresses malignancy of multiple myeloma by reducing the deubiquitinase USP5. J. Cell Biochem. 2020, 121, 642-650. [CrossRef] [PubMed]

155. Abdi, J.; Rastgoo, N.; Chen, Y.; Chen, G.A.; Chang, H. Ectopic expression of BIRC5-targeting miR-101-3p overcomes bone marrow stroma-mediated drug resistance in multiple myeloma cells. BMC Cancer 2019, 19, 975. [CrossRef] [PubMed]

156. Rastgoo, N.; Wu, J.; Liu, M.; Pourabdollah, M.; Atenafu, E.G.; Reece, D.; Chen, W.; Chang, H. Targeting CD47/TNFAIP8 by miR-155 overcomes drug resistance and inhibits tumor growth through induction of phagocytosis and apoptosis in multiple myeloma. Haematologica 2019. [CrossRef]

157. Jakob, C.; Sterz, J.; Zavrski, I.; Heider, U.; Kleeberg, L.; Fleissner, C.; Kaiser, M.; Sezer, O. Angiogenesis in multiple myeloma. Eur. J. Cancer 2006, 42, 1581-1590. [CrossRef]

158. Sun, C.; She, X.; Qin, Y.; Chu, Z.; Chen, L.; Ai, L.; Zhang, L.; Hu, Y. miR-15a and miR-16 affect the angiogenesis of multiple myeloma by targeting VEGF. Carcinogenesis 2013, 34, 426-435. [CrossRef]

159. Ghobrial, I.M. Myeloma as a model for the process of metastasis: Implications for therapy. Blood 2012, 120, 20-30.

160. Zhao, J.J.; Lin, J.; Zhu, D.; Wang, X.; Brooks, D.; Chen, M.; Chu, Z.B.; Takada, K.; Ciccarelli, B.; Admin, S.; et al. miR-30-5p functions as a tumor suppressor and novel therapeutic tool by targeting the oncogenic Wnt/beta-catenin/BCL9 pathway. Cancer Res. 2014, 74, 1801-1813. [CrossRef]

161. Chakraborty, C.; Wen, Z.H.; Agoramoorthy, G.; Lin, C.S. Therapeutic microRNAdelivery strategies with special emphasis on cancer therapy and tumorigenesis: Current trends and future challenges. Curr. Drug Metab. 2016, 17, 469-477. [CrossRef]

162. Segal, M.; Slack, F.J. Challenges identifying efficacious miRNA therapeutics for cancer. Expert Opin. Drug Discov. 2020, 15, 987-991. [CrossRef]

163. Van Rooij, E.; Marshall, W.S.; Olson, E.N. Toward microrna-based therapeutics for heart disease: The sense in antisense. Circ. Res. 2008, 103, 919-928. [CrossRef] [PubMed]

164. Vester, B.; Wengel, J. LNA (locked nucleic acid): High-affinity targeting of complementary RNA and DNA. Biochem. 2004, 43, 13233-13241. [CrossRef] [PubMed]

165. Gallo Cantafio, M.E.; Nielsen, B.S.; Mignogna, C.; Arbitrio, M.; Botta, C.; Frandsen, N.M.; Rolfo, C.; Tagliaferri, P.; Tassone, P.; Di Martino, M.T. Pharmacokinetics and pharmacodynamics of a 13-mer LNA-inhibitor-miR-221 in mice and non-human primates. Mol. Nucleic Acids 2016, 5, e336. [CrossRef] [PubMed]

166. Ebert, M.S.; Neilson, J.R.; Shapr, P.A. MicroRNA sponges: Competitive inhibitors of small RNAs in mammalian cells. Nat. Methods 2007, 4, 721-726. [CrossRef] [PubMed]

167. Choi, W.Y.; Giraldez, A.J.; Schier, A.F. Target protectors reveal dampening and balancing of Nodal agonist and antagonist by miR-430. Science 2007, 318, 271-274. [CrossRef] [PubMed]

168. Chen, L.; Li, C.; Zhang, R.; Gao, X.; Qu, X.; Zhao, M.; Qiao, C.; Xu, J.; Li, J. miR-17-92 cluster microRNAs confers tumorigenicity in multiple myeloma. Cancer Lett. 2011, 309, 62-70. [CrossRef] [PubMed]

169. Mogilyansky, E.; Rigoutsos, I. The miR-17/92 cluster: A comprehensive update on its genomics, genetics, functions and increasingly important and numerous roles in health and disease. Cell Death Differ. 2013, 20, 1603-1614.

170. Morelli, E.; Biamonte, L.; Federico, C.; Amodio, N.; Di Martino, M.T.; Gallo Cantafio, M.E.; Manzoni, M.; Scionti, F.; Samur, M.K.; Gullà, A.; et al. Therapeutic vulnerability of multiple myeloma to MIR17PTi, a first-in-class inhibitor of pri-miR-17-92. Blood 2018, 132, 1050-1063. [CrossRef] [PubMed]

171. Beg, M.S.; Brenner, A.J.; Sachdev, J.; Borad, M.; Kang, Y.K.; Stoudemire, J.; Smith, S.; Bader, A.G.; Kim, S.; Hong, D.S. Phase I study of MRX34, a liposomal miR-34a mimic, administered twice weekly in patients with advanced solid tumors. Investig. New Drugs 2017, 35, 180-188. [CrossRef] [PubMed]

172. Hong, D.S.; Kang, Y.K.; Borad, M.; Sachdev, J.; Ejadi, S.; Lim, H.Y.; Brenner, A.J.; Park, K.; Lee, J.L.; Kim, T.Y.; et al. Phase 1 study of MRX34, a liposomal miR-34a mimic, in patients with advanced solid tumours. Br. J. Cancer 2020, 122, 1630-1637. [CrossRef] 
173. Zarone, M.R.; Misso, G.; Grimaldi, A.; Zappavigna, S.; Russo, M.; Amler, E.; Di Martino, M.T.; Amodio, N.; Tagliaferri, P.; Tassone, P.; et al. Evidence of novel miR-34a-based therapeutic approaches for multiple myeloma treatment. Sci. Rep. 2017, 7, 17949. [PubMed]

174. Liu, Y.P.; Berkhout, B. miRNA cassettes in viral vectors: Problems and solutions. Biochim. Biophys. Acta 2011, 1809, 732-745. [CrossRef] [PubMed]

175. Wang, H.; Jiang, Y.; Peng, H.; Chen, Y.; Zhu, P.; Huang, Y. Recent progress in microRNA delivery for cancer therapy by non-viral synthetic vectors. Adv. Drug Deliv. Rev. 2015, 81, 142-160. [CrossRef] [PubMed]

176. Zilkowski, I.; Ziouti, F.; Schulze, A.; Hauck, S.; Schmidt, S.; Mainz, L.; Sauer, M.; Albrecht, K.; Jundt, F.; Groll, J. Nanogels enable efficient mirna delivery and target gene downregulation in transfection-resistant multiple myeloma cells. Biomacromolecules 2019, 20,916-926. [CrossRef] [PubMed]

177. Witwer, K.W. Circulating microRNA biomarker studies: Pitfalls and potential solutions. Clin. Chem. 2015, 61, 56-63. [CrossRef] [PubMed]

178. Gallo, A.; Alevizos, I. Isolation of circulating microRNA in saliva. In Circulating MicroRNAs; Kosaka, N., Ed.; Humana Press: Totowa, NJ, USA, 2013; Volume 1024, pp. 183-190.

179. Gasparri, M.L.; Casorelli, A.; Bardhi, E.; Besharat, A.R.; Savone, D.; Ruscito, I.; Farooqi, A.A.; Papadia, A.; Mueller, M.D.; Ferretti, E.; et al. Beyond circulating microRNA biomarkers: Urinary microRNAs in ovarian and breast cancer. Tumour Biol. 2017, 39, 1010428317695525. [CrossRef] [PubMed]

180. Wang, L.; Lv, J.; Guo, C.; Li, H.; Xiong, C. Recovery of cell-free mRNA and microRNA from human semen based on their physical nature. Biotechnol. Appl. Biochem. 2014, 61, 342-348. [CrossRef] [PubMed]

181. Turchinovich, A.; Weiz, L.; Langheinz, A.; Burwinkel, B. Characterization of extracellular circulating microRNA. Nucleic Acids Res. 2011, 39, 7223-7233. [CrossRef]

182. McDonald, J.S.; Milosevic, D.; Reddi, H.V.; Grebe, S.K.; Algeciras-Schimnich, A. Analysis of circulating microRNA: Preanalytical and analytical challenges. Clin. Chem. 2011, 57, 833-840. [CrossRef]

183. Kubiczkova, L.; Kryukov, F.; Slaby, O.; Dementyeva, E.; Jarkovsky, J.; Nekvindova, J.; Radova, L.; Greslikova, H.; Kuglik, P.; Vetesnikova, E.; et al. Circulating serum microRNAs as novel diagnostic and prognostic biomarkers for multiple myeloma and monoclonal gammopathy of undetermined significance. Haematologica 2014, 99, 511-518. [CrossRef]

184. Jiang, Y.; Luan, Y.; Chang, H.; Chen, G. The diagnostic and prognostic value of plasma microRNA-125b-5p in patients with multiple myeloma. Oncol. Lett. 2018, 16, 4001-4007. [CrossRef] [PubMed]

185. Sevcikova, S.; Kubiczkova, L.; Sedlarikova, L.; Slaby, O.; Hajek, R. Serum miR-29a as a marker of multiple myeloma. Leuk Lymphoma 2013, 54, 189-191. [CrossRef] [PubMed]

186. Gupta, N.; Kumar, R.; Seth, T.; Garg, B.; Sati, H.C.; Sharma, A. Clinical significance of circulatory microRNA-203 in serum as novel potential diagnostic marker for multiple myeloma. J. Cancer Res. Clin. Oncol. 2019, 145, 1601-1611. [CrossRef] [PubMed]

187. Shen, X.; Ye, Y.; Qi, J.; Shi, W.; Wu, X.; Ni, H.; Cong, H.; Ju, S. Identification of a novel microRNA, miR-4449, as a potential blood based marker in multiple myeloma. Clin. Chem. Lab. Med. 2017, 55, 748-754. [CrossRef]

188. Zhu, B.; Chen, H.; Zhang, X.; Pan, Y.; Jing, R.; Shen, L.; Wang, X.; Ju, S.; Jin, C.; Cong, H. Serum miR-30d as a novel biomarker for multiple myeloma and its antitumor role in U266 cells through the targeting of the MTDH/PI3K/Akt signaling pathway. Int. J. Oncol. 2018, 53, 2131-2144. [CrossRef]

189. Qu, X.; Zhao, M.; Wu, S.; Yu, W.; Xu, J.; Xu, J.; Li, J.; Chen, L. Circulating microRNA 483-5p as a novel biomarker for diagnosis survival prediction in multiple myeloma. Med. Oncol. 2014, 31, 219.

190. Ren, Y.; Li, X.; Wang, W.; He, W.; Wang, J.; Wang, Y. Expression of peripheral blood miRNA-720 and miRNA-1246 can be used as a predictor for outcome in multiple myeloma patients. Clin. Lymphoma Myeloma Leuk Leuk. 2017, 17, 415-423. [CrossRef]

(C) 2020 by the authors. Licensee MDPI, Basel, Switzerland. This article is an open access article distributed under the terms and conditions of the Creative Commons Attribution (CC BY) license (http://creativecommons.org/licenses/by/4.0/). 